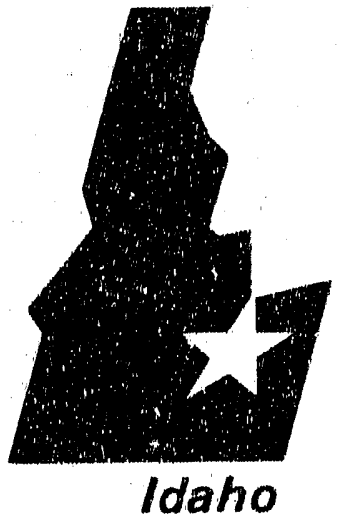

National

Engineering Laboratory

Managed

by the U.S

Department

of Energy
EGG-WTD-9989

May 1992

\section{Performance-Based Technology Selection Filter Description Report}

INEL Buried Waste Integrated Demonstration System Analysis Project
M. C. O'Brien

J. L. Morrison

R. A. Morneau

M. J. Rudin

J. G. Richardson
Received by 0ST

JUL. 231992

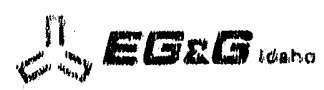

Work performers under DOE Contract NO. OE-ACO7.761001570 
This document contains new concepts or the author(s) irterpretation of new calculations and/or measurements; accordingly, EG\&G Idaho, Inc. is required by the United States Government to include the following disclaimer:

\section{DISCLAIMER}

This report was prepared as an acceunt of work sponsored by an agency of the United States Government. Neither the United States Goverment nor any agency thereof, nor any of their employees, makes any warranty, express or implied, of assumes any legal ilability or responsibility for the accuracy, completeness, or uselulness uf any intormain... apparatus, product or process disclosed ar represents that its isse would not iniringe privately owned rights. References herein to any specific commercial product, process, or service by trade name. trademark. manufacturer, or otherwise, does not neciessarily constitute or imply ils endorserneml, reconmendation, or favoring by the United States Government or any agency thereot. The views and opinions of authors expressed heren do not necessiatly state or roftect those of the Unuted States Govemment or ally ingency thereot 


\title{
Performance-Based Technology Selection Filter Description Report
}

\author{
INEL Buried Waste Integrated Demonstration \\ Systems Analysis Project
}

\author{
Michael C. O'Brien \\ John L. Morrison \\ Richard A. Morneau \\ Mark J. Rudin \\ John G. Richardson \\ Published May 1992 \\ Idaho National Engineering Laboratory \\ EG\&G Idaho, Inc. \\ Idaho Falls, Idaho 83415
}

Prepared for the

U.S. Department of Energy

Office of Environmental Restoration and Waste Management

Under DOE Idaho Field Office

Contract DE-AC07-76ID01570 


\section{Performance-Based Technology Selection Filter Description Report \\ INEL Buried Waste Integrated Denonstration \\ Systems Analysis Project}

EGG-WTD-9989

Prepared by:

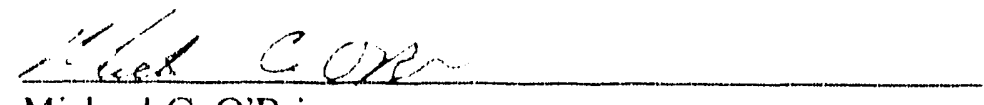

Michacl C. O'Brien

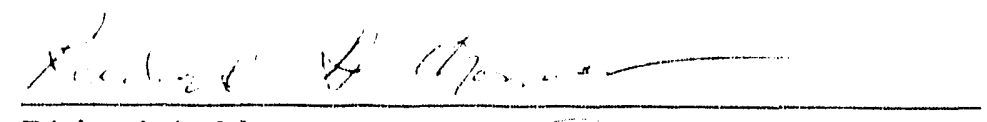

Richard A. Morneau

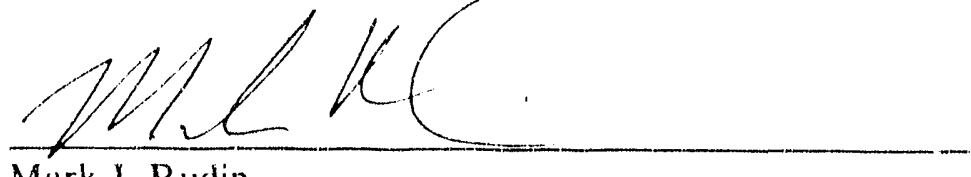

Mark J. Rudin

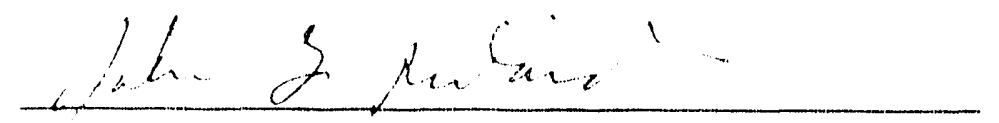

John G. Richardson

Reviewed and Approved by:
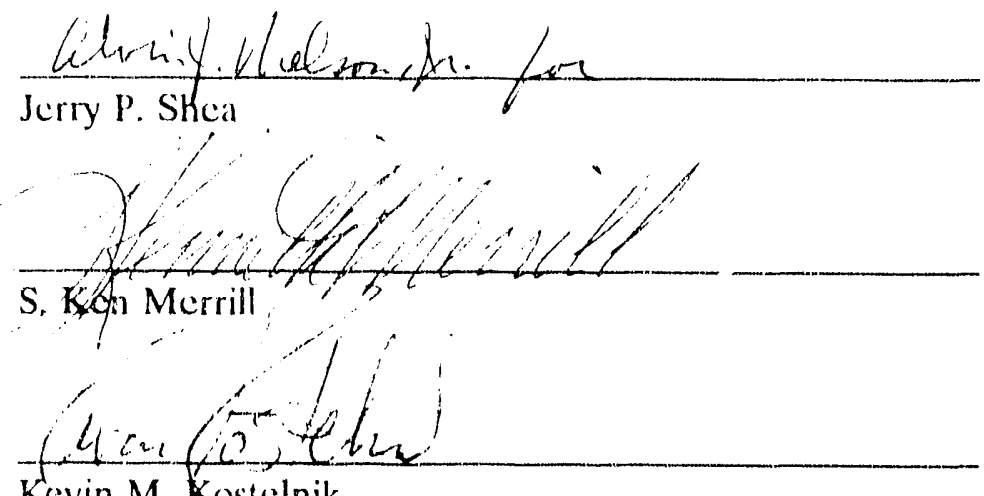

Kevin M. Kostelnik

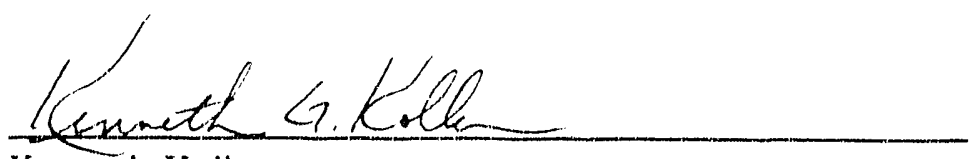

$5-20-72$

Date

$\frac{5 / 10 / 2}{\text { Date }}$
$\frac{5 / 20 / 92}{\text { Date }}$

$\frac{5 / 2 \% / 2}{\text { Date }}$

$5 / 20 / 92$

Date

$\frac{5 / 20 / 92}{\text { Date }}$

$\frac{5}{2 / 20 / 42}$

Date

$5 / 20 / 92$

Date

Kenneth Koller 


\begin{abstract}
A formal methodology has been developed for identifying technology gaps and assessing innovative or postulated technologies for inclusion in proposed Buried Waste Integrated Demonstration (BWID) remediation systems. Called the Performance-Based Technology Selection Filter, the methodology provides a formalized selection process where technologies and systems are rated and assessments made based on performance measures, and regulatory and technical requirements. The results are auditable, and can be validated with field data.
\end{abstract}




\section{SUMMARY}

The mission of the Buried Waste Integrated Demonstration (BWID) System Analysis is 10 identify and evaluate technology process options for the cradle-to-grave remediation of transuranic (TRU)-contaminated Waste Pits and Trenches buried at the Idaho National Engineering Laboratory (INEL). Emphasis is placed upon evaluating system configuration options and associated functional and operational requirements for retrieving and treating the buried wastes.

A Performance-Based Technology Selection Filter (PBTSF) has been developed to evaluate identilied remediation systems and their enabling technologies based upon system requirements and quantitation of technical Comprehensive Environmental Response, Compensation, and Liability Act (CERCLA) balancing criteria. Functionally, the filter is a tool that represents a formal methodology for selecting and rating lechnology process cptions. The PBTSF uses two components during its application. One component screens candidate technology process options against previously defined system requirements. The second component is the execution of trade-off studies rating technology process options against performance measures, and allows direct comparison between and among various systems and their constituent technologies.

Initially, generic configuration options are developed that provide a description of a remediation system at a functional subelement, or block diagram level. Next, technology process options are generated and formally assessed to determine if they meet system requirements. Those systems that do meet requirements are then addressed by the CERCLA-based trade-off study function. The output of the trade-off study function is a score (also called a rating) that indicates how well the technology process option rates against the CERCLA-based formulas.

Technology process options that do not meet functional requirements are examined to determine where performance must be improved or, more specilically, what performance aspects of varioiss functional subelements must be improved. Postulated innovative technologies are then inserted into the options and the options are then reevaluated against the requirements matrix. If a lechnology process option meets all system requirements, it is then scored via trade-off studies, and its overall periormance compared to scores of other technology process options. A score lower than other existing systems indicates that the postulated innovative technology will not benefit the process, and that new and higher performance requirements must be met to fill the technology gap.

This process can itcrate until a technology process option with a postulated technology generates a high system score. The assumed technology performance parameters then become requirements for technology development.

The BWID PBTSF is a systems tool whose purpose is to provide a framework and formal methodology for selection and rating of tech .ology process options and their enabling technologics. It also provides a closed-form approach to identify technology gaps and the requirements to fill those gaps. 
There are five primary attributes of the BWID PBTSF. These are:

- Technology process options and their enabling tewnologies are rated and selected based on performance measures

- Selection and ratings are based solely on regulatory and technical requirements, and are documentable and traceable

- Rating and selection is performed on complete technology process options

- Performance measures expressly define direct technology development

- Methodology is applicable to other remediation system analyses. 


\section{CONTENTS}

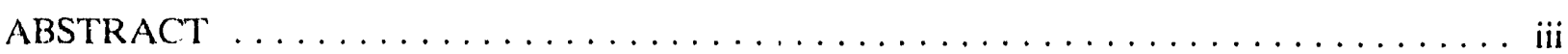

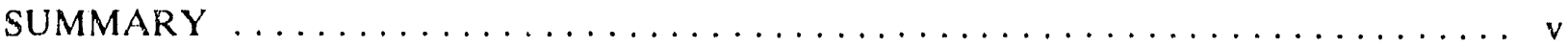

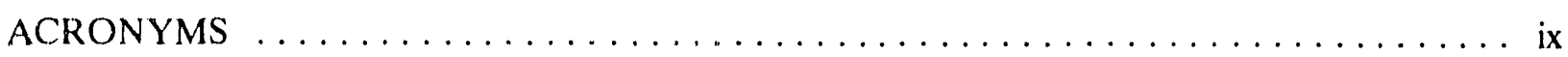

1. BWID SYSTEMS ANALYSIS PROJECT OVERVIEW $\ldots \ldots \ldots \ldots \ldots \ldots \ldots \ldots$

2. SYSTEM REQUIREMENTS $\ldots \ldots \ldots \ldots \ldots \ldots \ldots \ldots \ldots \ldots \ldots \ldots \ldots \ldots$

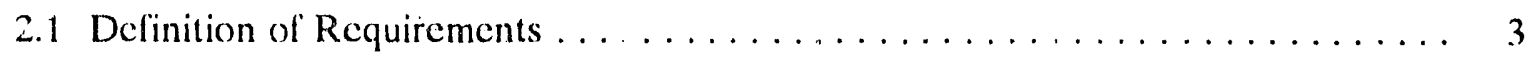

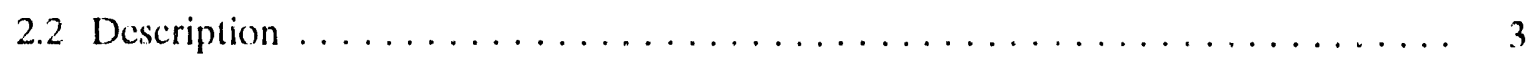

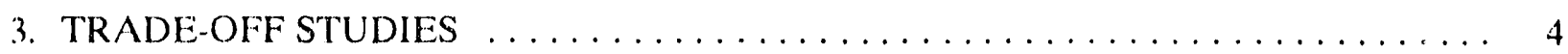

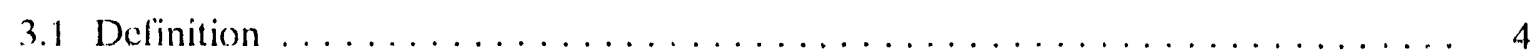

3.2 Derivation of Trade-Off Study Formulas $\ldots \ldots \ldots \ldots \ldots \ldots \ldots \ldots$

3.3 Roll-Up Methodology $\ldots \ldots \ldots \ldots \ldots \ldots \ldots \ldots \ldots \ldots \ldots \ldots$

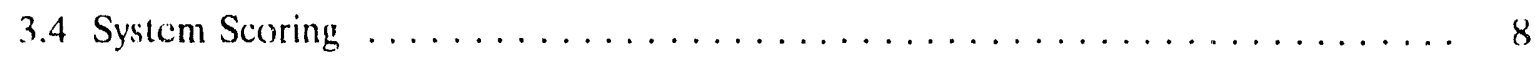

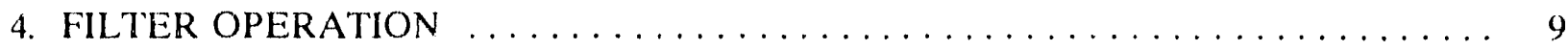

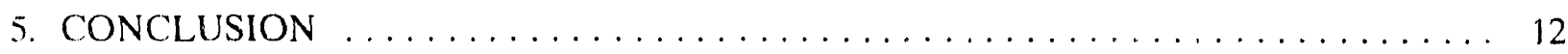

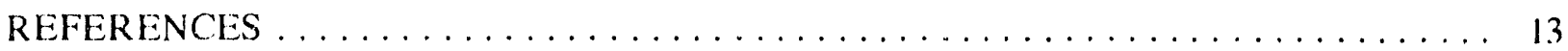

Appendix A-Conliguration Option Example $\ldots \ldots \ldots \ldots \ldots \ldots \ldots \ldots \ldots \ldots \ldots \ldots \ldots \ldots$

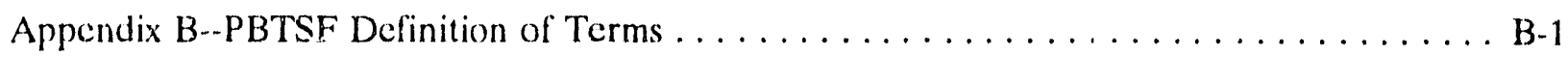

Appendix C--BWID Systems Analysis System Requirements $\ldots \ldots \ldots \ldots \ldots \ldots \ldots \ldots$

Appendix D--Filter Formula Derivation from CERCLA $\ldots \ldots \ldots \ldots \ldots \ldots \ldots \ldots \ldots$

\section{FIGURES}

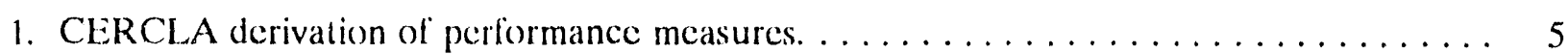

2. Performance-based technology selection filter methodology. $\ldots \ldots \ldots \ldots \ldots \ldots \ldots \ldots$ 


\section{TABLES}

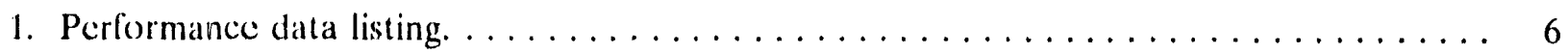




\section{ACRONYMS}

ARAR Applicable or relevant and appropriate requirement

BWID Buried Waste Integrated Demonstration

BWP Idaho National Enginecring Laboratory Environmental Restoration Buried Waste Plogram

CERCLA Comprehensive Environmental Response, Compensation, and Liability Act of 1980, as amended

CFR Code of Federal Regulations

DOE Department of Energy

EPA Environmental Protection Agency

ER Environmental Restoration

FFA COO Federal Facility Agreement and Consent Order

F\&OR Functional and Operational Requirement

FS Feasibility Study

HWSF Hazardous Waste Storage Facility

IAG Interagency Agreement (among DOE, EPA, and the State of Idaho

INEL Idaho National Engineering Laboratory

LLW low-level waste

I.SA Logistics, supportability, and availability

MIL-STDS Military standards (Dept. of Defense)

MWSF $\quad$ Mixed Waste Storage Facility

OU Operable Unit (as defined in the IAG)

PBTSF Performance-Based Technology Selection Filter

RD/RA Remedial Design/Remedial Action

RI/FS Remedial Investigation/Feasibinty Study 
ROD Record of Decision

RWMC Radioactive Waste Management Complex

SDA Subsurface Disposal Arca

TAG Technical Advisory Group

TRU transuranic

TTP Technical Task Plan

WAC Waste A.ceeptance Criteria 


\section{Performance-Based Technology Selection Filter Description Report}

\section{INEL Buried Waste Integrated Demonstration Systems Analysis Project}

\section{BWID SYSTEMS ANALYSIS PROJECT OVERVIEW}

The mission of the Buried Waste Integrated Demonstration (BWID) Systems Analysis is to identify and evaluate systems for the cradle-to-grave remediation of transuranic (TRU)-contaminated Waste Pits and Trenches located within the Subsurface Disposal Area (SDA) of the idaho National Enginecring Laboratory's (INEL) Radioactive Waste Management Complex (RWMC). There are three distinct objectives of the project:

- Dired U.S. Department of Encrgy (DOE) resources to develop technically sound and cost-effective systems for the complete remediation of DOE buried waste sites

- Guide the selection and technical justification for the development and demonstration of technologies within the BWID program

- Identify system technology gaps and define quantitative perlormance requirements for technologies associated with the remediation of DOE Complex buried wastes.

The BWID program will use the results of the Systems Analysis in conjunction with identified DOE Complex buried waste needs to develop a long-term strategy for improving buried waste remediation capabilities throughout the DOE system.

Initial activities within the BWID Systems Analysis project involve identifying configuration options capable of remediating the TRU-contaminated Waste Pits and Trenches at the INEL. A conliguration option is defined as a top-level block diagram of a cradle-to-grave remediation system. An example of a configuration option is attached as Appendix A. An earlicr report ${ }^{1}$ identified and pre-sereened a number of possible remediation conliguration options per criteria set forth in DOE Order 4700.1, Project Management Systems. The report recommended the following three conliguration options for future evaluation: Retrieve/Ex Situ Thermal Treatment, Retrieve/Chemical Oxidation and Solidification, and In Situ Vitrification/Retrieval. The current focus of the BWID Systems Analysis is to perform a rigorous evaluation of the Retrieve/Ex Situ Thermal Treatment Configuration Option. The Retrieve/Chemical Oxidation and Soliditication, and the In Situ Vitrification configuration options will be studied further at a later date.

Each block within a configuration option performs a function within a system and is relerred to as a "lunctional subelement." Functional and operational requirements (F\&ORs) are defined for each functional subelement within the Retrieve/Ex Situ Thermal Treatment configuration option. The F\&ORs will then direct the insertion of specific technologies into each functional subelement resulting in the formulation of technology process options (systems). A technology process option is a Comprehensive Environmental Response, Compensation, and Liability Acl (CERCLA) term used 
to describe a configuration option that has sperific technologies or requirements defined or all functional subelements. The terms "system" and "technology process option" are used synonymously in the BWID Systems Analysis project.

The BWID Performance-Based Technology Selection Filter (PBTSF) is a tool developed within the scope of the BWID Systems Analysis that represents a formal methodology for selecting and rating candidate remediation lechnology process options. The PBTSF uses two components during its application. One component screens candidate systems against system requirements. The second component involves executing rrade-off studies that rate technology process options against performance measures based on CERCLA selection criteria. This approach allows direct comparison between and among various systems and their enstituent technologies.

This report pibvides a preliminary description of the various leatures of the PBTSF, as welf as an explanation of its overall operation. A list of PBTSF-specific terms and their definitions is attached as Appendix B. 


\section{SYSTEM REQUIREMENTS}

\subsection{Definition of Requirements}

System requirements are delined in the PBTSF as a set of top-kevel constraints that guide the development and selection of viable remediation systems from a population of candidate remediation systems. These systems requirements are not the same as F\&ORs associated with each of the functional subelements within a particular system.

\subsection{Description}

The selection of a remediation system is constrained by requirements such as waste/site characteristics, applicable or relevant and appropriate requirements (ARARs), and programmatic requirements defined by the U.S. Environmental Protection Ageney (EPA), the U.S. Department of Energy, the State of Luaho, and the BWID program. PBTSF system requirements are limited to those requirements that significantly affect the viability of a specific technology process option.

The system requirements, which are presented in Appendix $C$, have been generated from a combination of technical and regulatory sources including:

- Irogrammatic Requirements

Federal Facility Agreement and Consent Order (FFA/CO) (U.S. EPA, U.S. DOE, and State oŕ Idaho) $)^{2}$

BWID Demonstration Plan ${ }^{3}$

- Input Requirements

Historical and technical characterizations of the INEL Subsurface Disposal Arcal $^{4,1}$

- Output Requirements

INEL RWMC Low Level Waste Acceptance Cricria ${ }^{5}$

INEL TRU Waste Acceptance Criteria"

INEL RWMC Pad A ARARs"

a. D. A. Arrenholz, and J. L. Knight, Historical Report of Transuranic Waste Pits and Trenches at the Subsurface Disposal Area of the Radioactive Waste Management Complex at the INEL, WTD-91-027. August 1991.

b. Unpublished letter from S. G. Stiger (INEL Environmental Restoration) to W. N. Satc (DOE ID), Transmittal of the Revised Pad A Technical Memorandum on the Preliminary Idontification of Combined Federal and State Applicable or Relevant and Appropriate Requirements (ARARs), SGS-15-91, December 5, 1991. 


\section{TRADE-OFF STUDIES}

\subsection{Definition}

PBTSF trade-off studies are defined as a formal methodology to score technology process options using performance measures.

\subsection{Derivation of Trade-Off Study Formulas}

Since the INEL is designated as a Superfund site, it is appropriate to consult CERCLA to guide the evaluation of the candidate technology process options for remediating the TR.U. contaminated Waste Pits and Trenches at the INEL. CERCLA provides the framework for evaluating end-to-end technology process options, or alternatives during a Feasibility Study (FS). The PBTSF methodology can be used for evaluating remedial alternatives for any Operable Unit at a CERCLA site or at a non-CERCLA site that is interested in conducting trade-off studies.

The primary objective of a CERCLA Feasibility Study is "to ensure that appropriate remedial alternatives are developed and evaluated such that relevant information concerning the remedial action eptions can be presented to a decision-maker and an appropriate reriedy selected" (see Refereace 2). A report entitled Guidance on Feasibility Studies Under CERCLA EPA/540/G-85/003 and a revision entilled Guidance for Conducting Remedial Investigations and Feasibility Studie, Inder CERCLA EPA/540/G-89/004 identify three categories of criteria that should be considered while evaluating technology process options-effectiveness, implementability, and cost. Twenty-two performance measures have heen identified that reflect the text or implied meaning of the text associated with each evaluation criteria in the EPA guidance documents (see Figure 1). Excerpts of text that provide the basis for each performance measure factor are presented in Appendix D.

Formulas were developed that are used to generate numerical scores associated with each performance measure. These indicate quantitatively how well a technology process option performs relative tw each performance measure. Appendix D lists these formulas. Inputs to the formulas are various system technical and institutional performance characteristics of the technology process option and are referred to as performance data (see Table Inputs to the formulas are various system technical and institutional performance characteristics of the technology process option and are referred to as performance data (see Table 1). The following example illustrates the terminology associated with formulas and performance measures used within the PBTSF trade-off studies:

\section{Example:}

Criteria Calegory:

Contributing Factor:

Formula:

Performance Measure:

Performance Data:

$$
\begin{aligned}
& \text { Effectiveness } \\
& \text { Volume Reduction } \\
& \mathrm{E} 1=1 . \mathrm{Vo} / \mathrm{Vi} \\
& \mathrm{E} 1 \\
& \mathrm{Vo}, \mathrm{Vi}
\end{aligned}
$$

Sources of performance data include manufacturers, proposers, lessons learned from technology demonstrations, and input requirements. When a system or technology has not been demonstrated, 

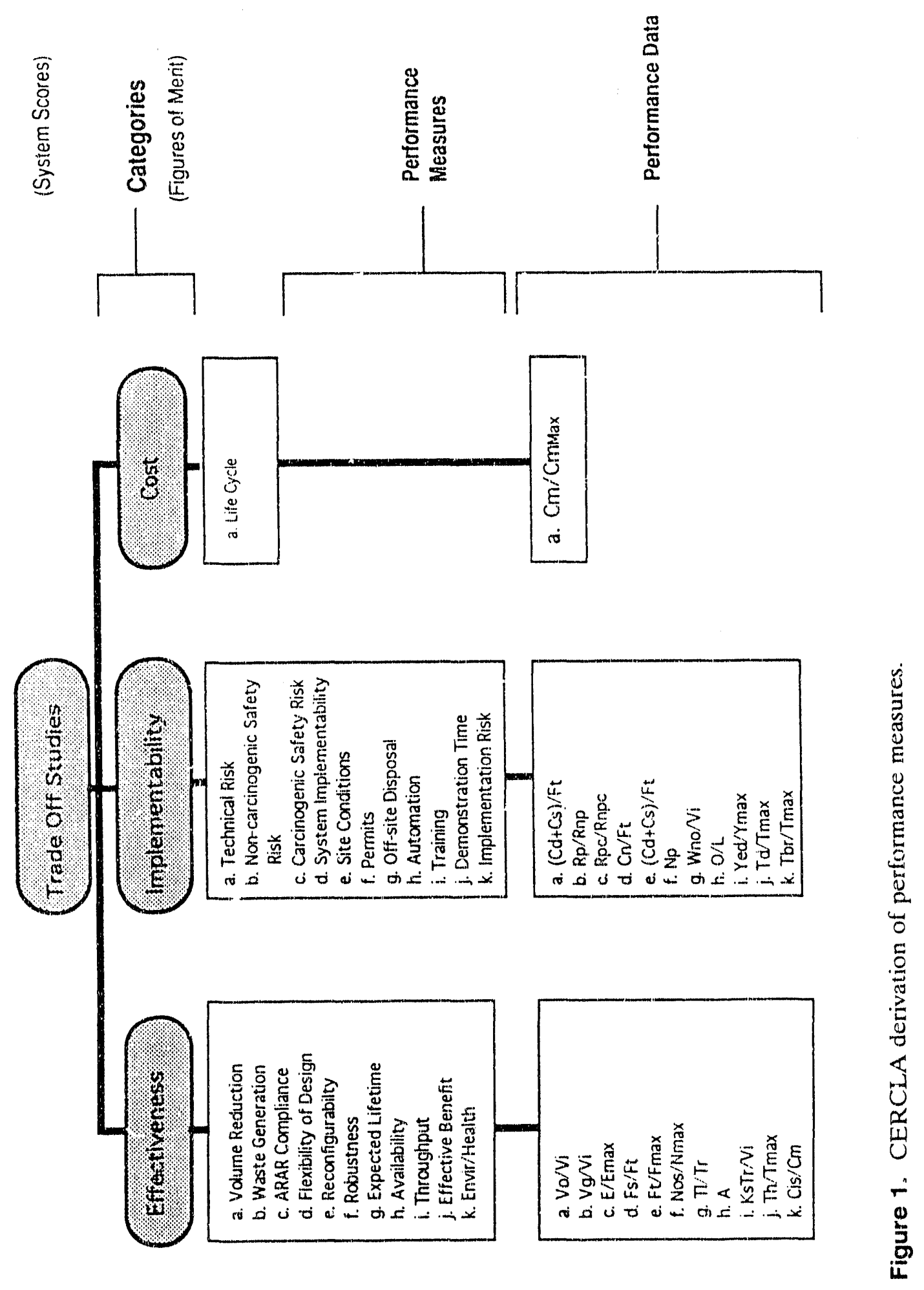
Table 1. Performance data listing.

1. $\quad V_{0}=$ The volume $\left(\mathrm{m}^{3}\right)$ of output material from the process which requires monitoring and sturage (includes any contaminated process material).

2. $\quad \mathrm{V}_{\mathrm{i}}=$ The volume $\left(\mathrm{m}^{3}\right)$ of waste seam, matrix, overburden, and horizontal plume as defined in the input requirements.

3. $\quad \mathrm{V}_{\mathrm{g}}=$ The volume $\left(\mathrm{m}^{3}\right)$ of contaminated process material produced by the system.

4. $\quad E=$ Number of process-specific ARARs.

5. $\quad F_{\mathrm{s}}=$ COTS functional subelements.

6. $\quad F_{1}=$ Total functional subelements.

7. $\mathrm{N}_{\mathrm{OS}}=$ Number of predefined oli-ui-scope inputs the system can remediate.

8. $\quad T_{1}=$ Time until necessary line item and capital equipnient replacenent costs exceed $50 \%$ of acquisition cost.

9. $\mathrm{T}_{\mathrm{r}}=$ Time to remediate $\mathrm{V}_{\mathrm{i}}$.

10. $\quad \mathrm{A}=$ Availability

11. $\mathrm{T}_{\mathrm{h}}=$ Time to remediate $50 \%$ of $\mathrm{V}_{\mathrm{i}}$.

12. $\quad \mathrm{C}_{\text {is }}=$ Important-to-safety expense

13. $\mathrm{C}_{\mathrm{m}}=$ Cost (life cycte).

14. $\quad C_{d}=$ Number of subelements demonstrated under similar site and waste conditions.

15. $\quad \mathrm{C}_{\mathrm{s}}=$ Number of subelements similar but not identical to a technology demonstrated under similar site and waste conditions.

16. $\quad R_{p}=$ Hazard Index $w /$ process.

17. $R_{n p}=$ Hazard Index w/o process.

18. $\quad R_{p c}=$ Excess lifetime cancer risk $w /$ process $\left(10^{-6}\right)$ 
Table 1. (continued).

19. $\quad \mathrm{R}_{\mathrm{npc}}=$ Excess lifetime cancer risk w/o process $\left(10^{-6}\right)$.

20. $\mathrm{C}_{\mathrm{n}}=$ Number of subelements not able to be demonstrated prior to full-scale implementation.

21. $\mathrm{N}_{\mathrm{p}}=$ Number of special permits required specific to the remediation.

22. $\mathrm{W}_{\mathrm{no}}=$ Volume of waste that cannot currently be moved to offsite disposal.

23. $\mathrm{L}=$ Operation labor hours.

24. $\mathrm{O}=$ Operation hours.

25. $\quad y=$ Mean years of specialized training (academic and facility specific).

26. $\quad \mathrm{T}_{\mathrm{d}}=$ Total critical path time to demonstrate.

27. $\quad \mathrm{T}_{\mathrm{br}}=$ Time to begin remediation. 
performanee data must be estimated and the uneertainty associated with the estimate identified. The Department of Defense Logistics, Supportability, and Availability (LSA) is an example of a technique that can be used 10 arrive at performance data estimates. Technical teams wi'l review all performance data to ensure their validity. All input performance data, actual or estimated, will be documented for further refierence.

All formulas generate performane measures whose values mostly fall between one and zero. One indicates high, or desirable performance, and zero indicates low, or undesirable performance.

\subsection{Roll-Up Methodology}

The perfortiance data used to calculate performanee measures may ne collected at the system or the technology level. If the performanee data are collected at the technology level, the data must be combined or "rolled-up" to generate system level performance data. This process is discussed in Appendix D. Techniques for rolling up data uncertainties have also been developed and are described in Appendix D.

\subsection{System Scoring}

Averaging all performance measures that contribute to a criteria category (Effectiveness, Implementability, or Cost) generates a number that is defined as the final value or "figure-of-merit". If desired, different weighting factors can be applied to each of the performance measures. This could be used 10 reflect the relative levels of importance of some measures over others.

An overall score for a technology process option is calculated by averaging the three figures of merit lor Effectiveness, Implementability and Cost. Again, different weights can be applied to each of the three categories.

Note that CERCLA does not address the relative weighting of the parts that make up each category, nor does it address the relative weights of the categories to cach other. The PBTSF is implemented using a computer program that will allow all the weightings to be set by Environmental Restoration, Buried Waste Program/BWID program. 


\section{FILTER OPERATION}

Figure 2 illustrates the sequence of steps followed in the PBTSF to rate competing technology process options and generate specific lechnology development requirements. This section provides a detailed description of the various elements shown in Figure 2.

Initially, generic configuration options are developed that provide a description of a remediation system at a functional subelement level. Many possible technology process options may reflect the same configuration option, and differ only in performance characteristics of certain subelements. An example might be a melting and incinerarion configuration option analyzed with several diflerent metal shredders. While each technology process option would have the same block diagram, their end-to-end performance characteristics will reflect each specific shredder technology. Candidate configuration options will be evaluated from a scientific/enginecring standpoint to determine future consideration. Reasons for evaluating particular configuration options will be fully decumented for future reference.

Specific technologies or performance requirements are defined for each functional subelement within a configuration option to develop technology process options. Technical experts will be consulted to provide and screen technology lists that are considered for each functional subelement. Again, reasons for considering technologies within a particular functional subelement will be fully documented for future relerence.

Technology process options are formally assessed to determine if they meet system requirements. The results of applying the system requirements matrix will indicaic explicitly which technology process options are or are not meeting system requirements and why. Those systems that do meet requirements are then addressed by the trade-off study function. The output of the trade-off study function is a score for each technology process option (also called a rating) that indicates how well the technology process options rate against the CERCLA-based formulas discussed in Section 3.

Technology process options that do not meet functional requirements are examined to determine where performanec must be improved or, more specifically, what perlormanee aspects of various functional subclements must be improved. An example might be a technical process candidate generating a waste form that cannot meet output requirements. Performance requirements are then defined at the subelement level such that system requirements can be met. Note that there may be one or more subelements that are responsible for a technology process option not meeting requirements. Thus, performance requirements may be identilied for more than one subelement within a technology process option. These gaps, defined by performance requirements, may be filled by existing technologies that were not initially considered, or postulated innovative technologies. This process is called identification of technology gaps.

Postulated innovative technologies, as defined by their performance measures, are inserted into technology process options that do not meet system requirements, and the option is then reevaluated against the requirements matrix. If the technology process option meets all system requirements, it is then scored via trade-off studies, and its overall performance compared to scores of other technology process options. A score lower than other existing systems indicates that the postulated 


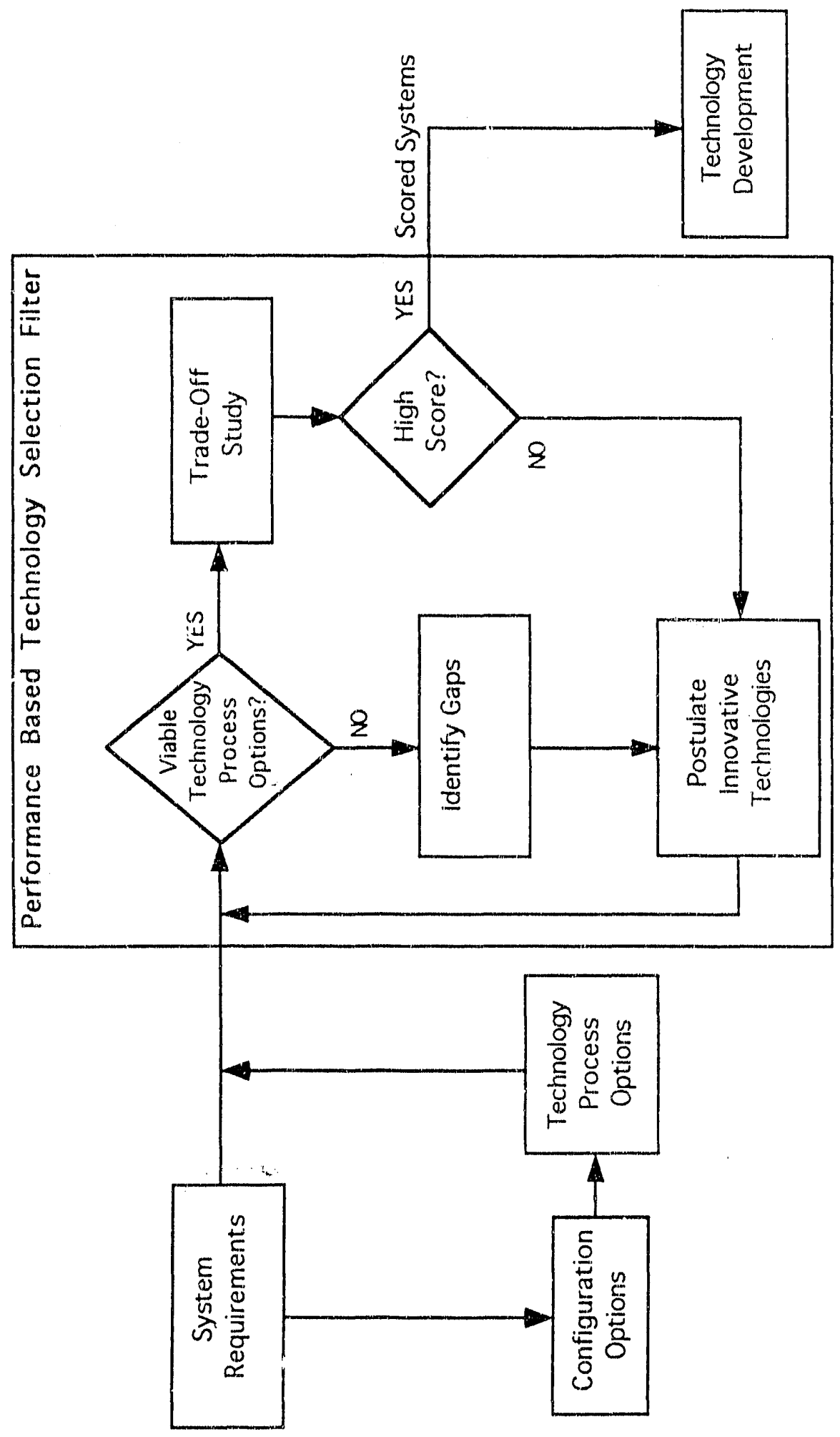

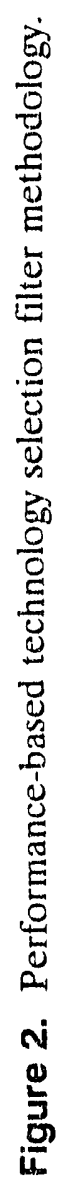


innovative technology will not benefit the process, and that new and higher performance requirements must be met to fill the technology gap.

This process can be iterated until a technology process option with a postulated teclınology generates a high system score. The assumed technology performance parameters then become requirements for technology development. Note, again, that requirements that the technology must meet are directly related to the score the technology process option must attain in order to compare favorably with existing technology process options that require litte, if any lurther development. 


\section{CONCLUSION}

The BWID PBTSF is a systems tool whose purpose is to provide a framework and formal methodology for sclection and rating of technology process options and their enabling technologies. It also provides a closed-form approach to identify technology gaps and the requirements to fill those gaps.

There are live primary attributes of the BWID PBTSF. These are:

- Technology process options and their enabling technologies are rated and selected based on performance measures

- Selection and ratings are based solely on institutional and technical requirements, and ate documentable and traceable

- Rating and selection is performed on complete systems

- Performance measures expressly define direct technology development

- Methodology is applicable to other remediation system analyses. 


\section{REFERENCES}

1. J. L. Mayberry, F. Feizollahi, J. C. Signore, and W. J. Quapp, Preliminary Systems Design Study Assessment Report, EGG-WTD-9594, Novernber 1991.

2. Federal Facility Agreement and Consent Order, ADN: 1088-06-29-120, Idaho National Engincering Laboratory, May 1991.

3. K. M. Kostclnik, Buried Waste Integrated Demonstration Plan, EGG-WTD-9870, December 1991.

4. D. A. Arrenholz and J. L. Knight, A Brief Analysis and Description of Transuranic Wastes in the Subsurface Disposal Area of the Radioactive Waste Management Complex at INEL, EGG-WTD-94.38 Rev. 1, 1991.

5. U.S. Department of Energy Idaho Field Office (DOE-ID), INEL Low-Level Radioactive Waste Acceptance Critcria, DOE/ID-10112 Rev. 4, October 1991.

6. U.S. Department of Energy Idaho Field Office (DOE-ID), INEL Transuranic Waste Acceptunce Criteria, DOE/ID-100074, May 1991. 
Appendix A

Configuration Option Example 


$$
\text { A-2 }
$$




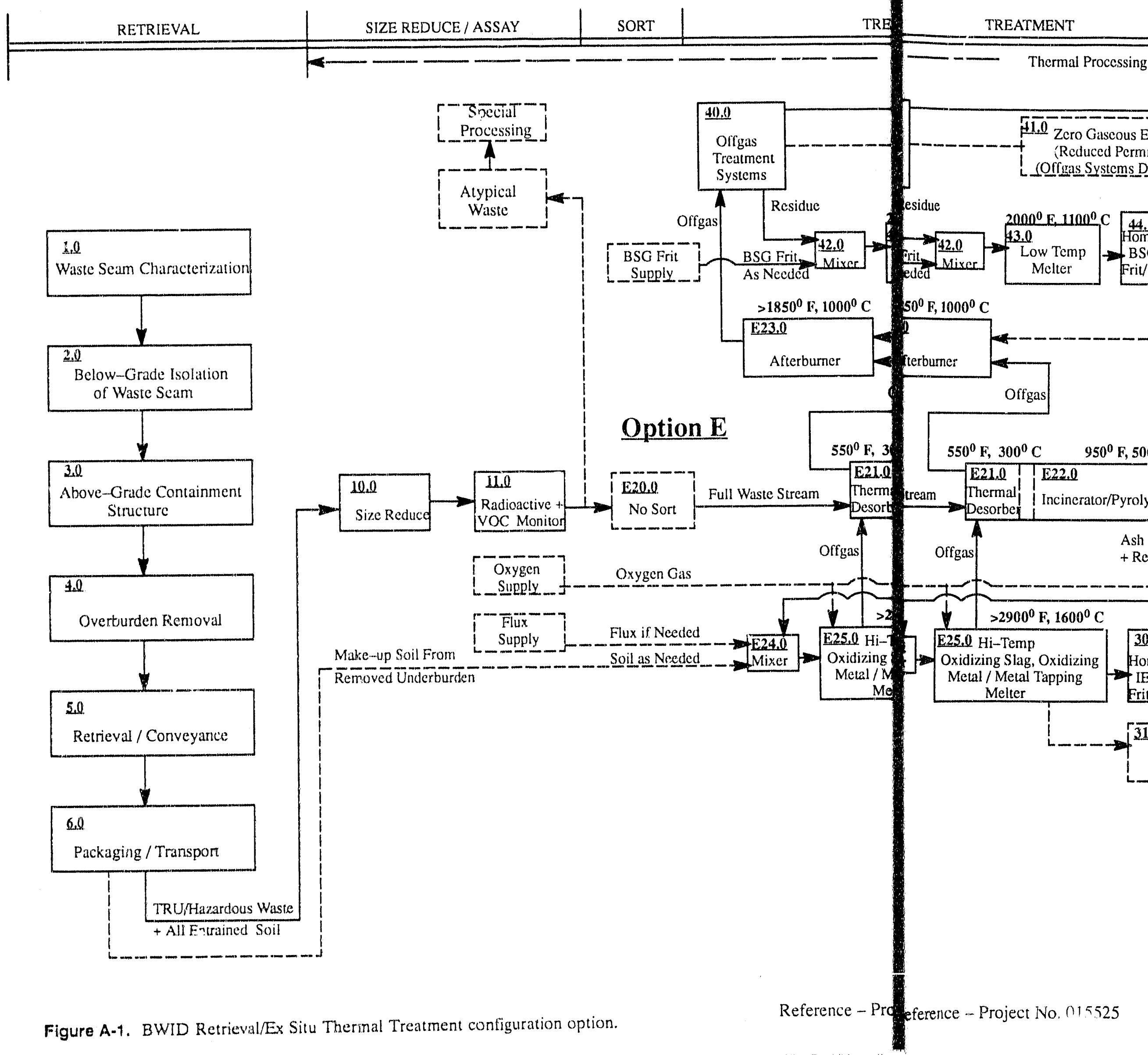




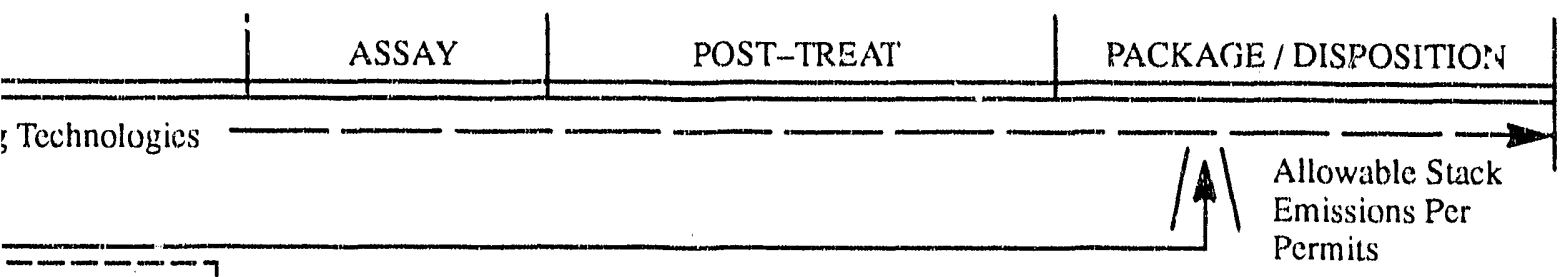

Emissions it Scope) gevelopment

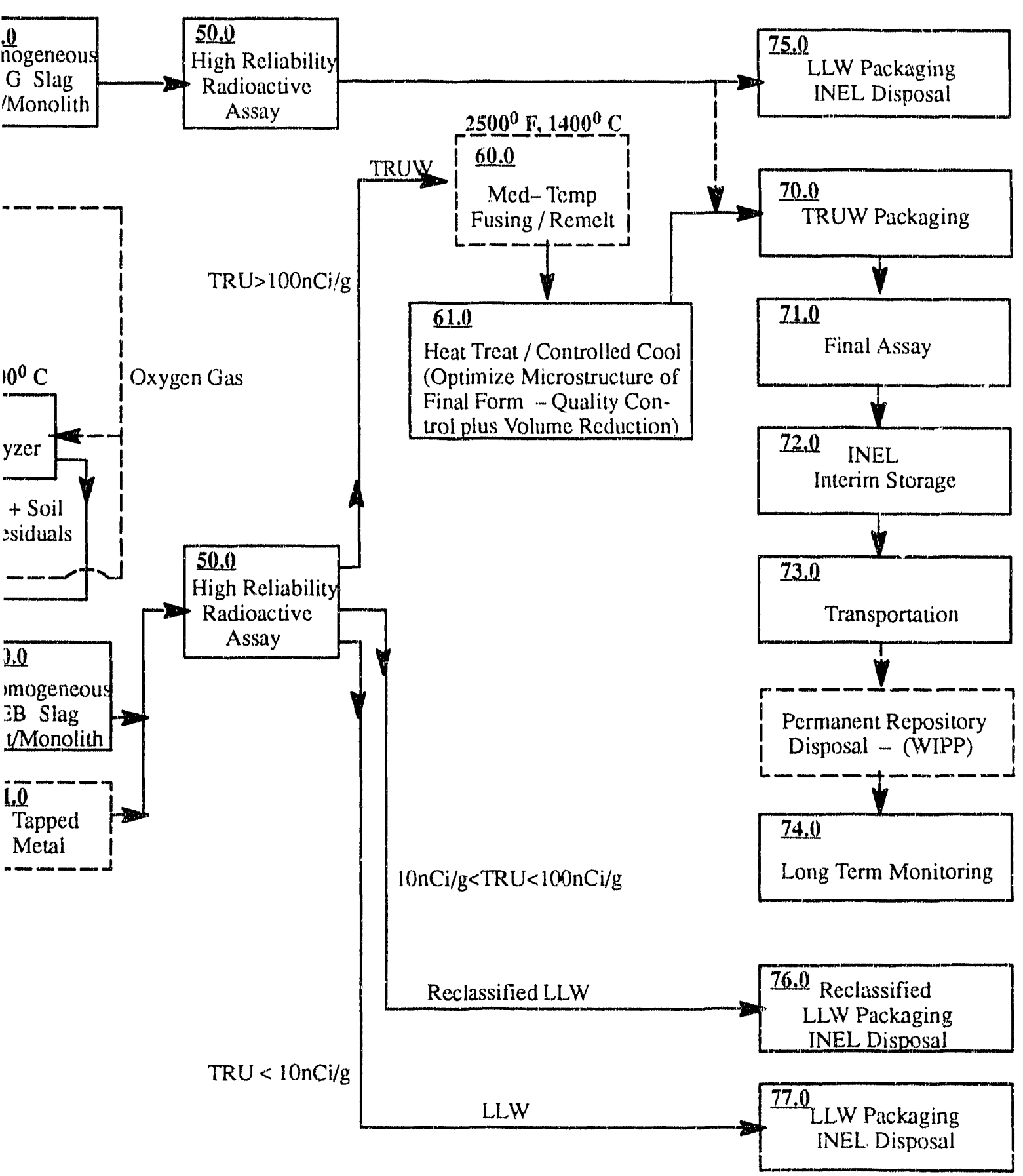




\section{Appendix B}

\section{PBTSF Definition of Terms}




\section{Appendix B}

\section{PBTSF Definition of Terms}

Configuration option

Contributing factor

Driver

Figure of merit

Functional subelement

Gencral calegory

Perlormance measure

Similar subelement

Technology process option
Top-level block diagram of a cradle-to grave remediation whose overall performance is specified by system requirements.

Defined indicator of one aspect of system performance derived from criteria used to evaluate technology process options.

Intuitively meaninglul indicator of contributing factor performance.

Numerical score or rating of a general category (effectiveness, implementability, and cost).

One or more integrated components assembled to periorm a function whose performance can be specified by the system requirements.

One of the CERCLA development and screening criteria used in the filter to roll up scores (effectiveness, implementability, and $\cos t$ ).

System technical or institutional performance characteristic, used as input to formulas.

Undemonstrated subelement that is similar to a demonstrated subelement.

Configuration option with specific technologies or requirements defined for all functional subelements 
Appendix C

BWID Systems Analysis System Requirements 


\section{Appendix C}

\section{BWID Systems Analysis System Requirements}

\section{Programmatic Requirements}

Only systems that characterize, retrieve, process, treat, package, and dispose of wastes buricd in Pits 1-6, 9-15, 17, and Trenches 1-15, 19, 20, 26, 32, 34, 39, 45, 47-49, 51, and 55 of the Idaho National Engineering Laboratory (INEL) Subsurface Disposal Area (SDA) will be considered for further evaluation in this analysis. This particular group of disposal pits and trenches is called the Transuranic (TRU)-contaminated Waste Pits and Trenches and is designated by INEL Environmental Restoration as Operable Unit (OU) 7-13. Other lypes of remediation efforts such as in situ stabilization, containment/monitoring, and in situ treatments will not be considered in this phase of the Buried Waste Integrated Demonstration (BWID) Systems Analysis.

The U.S. EPA/State of Idaho/U.S. DOE Federal Facility Agreement and Consent Order ${ }^{1}$ states, "The RD/RA process will be streamlined, to the extent possible, to meet the CERCLA requirement to commence substantial continuous physical on-site remedial action within 15 months of issuance of a ROD." Since a draft Record of Decision (ROD) is required for the TRUcontaminated Waste Pits and Trenches by July 1998, then a ROD will most likely be issued in 1999. Fifteen months after that date is in the year 2000. The requirement is that substantial actual remediation stari in the year 2000 . The implication is that remedial technologies must be sufficiently developed or developable so full-scale field implementation could begin no later than the year 1998. It might be that retrieval could begin in 1998 and separation/processing could be delayed as much as a couple of years. However, storage facilities would be required for the retrieved, unseparated waste/soil.

A draft Remedial Investigation/Feasibility Study (RI/FS) report for the TRU-contiaminated Waste Pits and Trenches must be submitted to regulators for review by September 1997 per the U.S. EPA/State of Idaho/U.S. DOE Federal Facility Agreement and Consent Order. The results of any treatability study would be included in the RI/FS report. The results of the RI/FS must be sufficiently promising and rigorous to convince the reviewing regulators that the technology is viable for the response action. Therefore, technologies must be sufficiently developed or capable of development such that any required treatability studies could be successfully completed and documented by Seplember 1997.

The 1991 DOE-HQ Environmental Restoration and Waste Management Five-Year Plan ${ }^{2}$ states that remedial activities be completed by the year 2019. Therefore, technologies must be sufficiently developed or capable of development, and must have sufficient throughput, that the remediation of the TRU-contaminated Waste Pits and Trenches can be completed by the year 2019. 


\section{Input Requirements}

\section{Input Requirements Based on Physical Characteristics of Waste}

A configuration option must be abie to remediate the region within each pit or trench that encompasses the original excavation down to the depth of the underlying basalt. The boundary that defines the unit of waste (overburden, sideburden, underburden, and debris) to be retrieved is referred 10 as the "waste seam."

A configuration option must be able to characterize, retricve, process, treat, package, and dispose of the following volumes of soil currently disposed of in the INEL TRU-contaminated Waste Pits and Trenches: $:^{3,4}$

- $2,100,000 \mathrm{ft}^{3}$ of underburden soil probably contaminated with radionuclides, metals, inorganic compounds, and organic conpounds listed in Table C-1.

- $\quad 3,900,000) \mathrm{nt}^{3}$ of interstitial soil probably contaminated with radionuclides, metals, inorganic compounds, and organic compounds listed in Table $\mathrm{C}-1$.

- $\quad 3,650,000 \mathrm{ft}^{3}$ of overburden soil potentially contaminated with radionuclides, metals, inorganic compounds, and organic compounds listed in Table C-1. Nonhazardous and non-TRU overburden that is removed will be placed back into the excavated pit or trench after retrieval operations are complete. Hazardous, TRU, and mixed waste soil will be packaged for treatment.

A configuration option must be able to remediate 160,50055 -gal or 120 -gal stecl drums assumed to be badly deteriorated.

A conliguration option must be able to remediate 6,500 cardboard and plywood boxes ranging in size from $4 \times 4 \times 7 \mathrm{ft}$ to $8 \times 8 \times 18 \mathrm{ft}$ and weighing up to 5,000 $\mathrm{lbs}$. The boxes are assumed to be badly detcriorated.

Boxes and drums are expected to contain the types of contaminated items listed in Table C-1.

A configuration must be able to retrieve, process, treat, and dispose of the following kinds of infrequently-encountered contaminated buried items that are up to 12,000$) \mathrm{lbs}$ and size of $4 \times 4 \times 8$ fit.

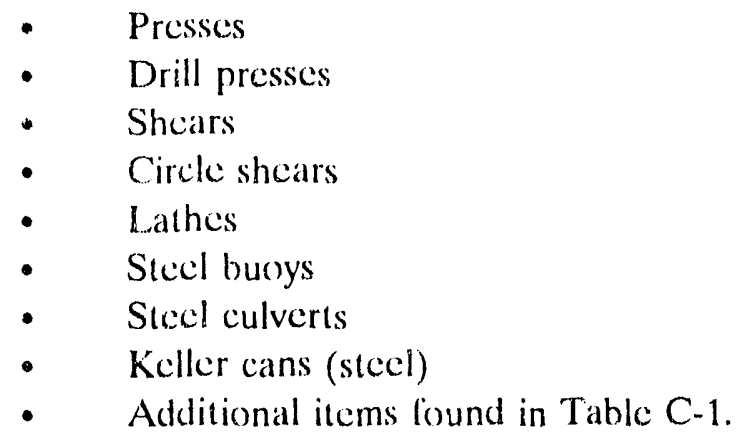


Table C-1. Summary makeup of wastes buried in the SDA at RWMC (see References 3 and 4).

\section{Construction and Demolition Matcrial}

Lumber, wallboard, steel plate and shapes, ducting, electrical wires, fuse boxes, roofing material, floor lile, insulation, lead sheet and bricks, asphalt paving material, soil, sand, gravel, stecl stairways, ladders, and concrete blocks.

\section{Laboratory Equipment and Materials}

Hoods, laboratory benches, desks, chairs, cabinets, glassware, plastic tubing, plastic and glass bottles, solutions stabilized in concrete, plaster, or vermiculite.

\section{Process Equipment}

Tanks, heat exchangers, tube bundles, conde'sers, vacuum pumps, piping, cut up wide flange beams, valves, organic wastes, ion exchange resins, zirconium plate, zirconium turnings, sawdust, HEPA lilters, steel buoys, and steel culverts.

\section{Maintenance Equipment}

Hand tocks, metal-working machines, hoists, welders, oils and grease, metal filings, abrasive whecls and sheet, drill presses, shear, circle shear, lathes, bridge crane with rails, casting furnaces, and coating furnaces.

\section{Decontamination Matcrials}

Paper, rags, plastic bags and sheet, floor sweepings, brooms, and steel wool.

\section{Miscellancous}

Sewer sludge, garbage, animal remains and excreta, jet engines, vehicles, Test Reactor Area fuel end boxes, 55-gal and 120-gal steel drums (assumed to be badly deteriorated), cardboard boxes (ass'dmed to be badly deteriorated), reactor shicld, storage tanks, and keller cans.

Note: Table $\mathrm{C}-1$ is a listing for the entire SDA. For the purposes of this study, it is considered to be representative of the types of wastes believed 10 be buried in the INEL TRU-contaminated Waste Pits and Trenches (OU 7-13). 
A system must be able to characterize and relocate the following kinds of infrequentlyencountered oversize anci overweight contaminated items (includes any items greater than $12,000 \mathrm{lbs}$ and $4 \times 4 \times 8(t)$ :

- $\quad$ 14-in and 24-in wide flange beams, cut (length unknown)

- $\quad$ Concrete blocks $150 \mathrm{ft}^{3}-284 \mathrm{ft}^{3}, 13.95$ tons average

- Concrete conduits, up to 3 tons each

- Aluminum heat exchangers, 26.5 ft length x $5 \mathrm{ft}$ diameter, 19,960 lbs.

- Some additional oversize and overweight items are listed in Table 1 of this Appendix (c.g., bridge crane with rails)

These infrequently-encountered oversize and/or overweight and/or high activity items are considered "atypical wastes" and may be left on the floor of the excavated pit or trench and/or shiclded and/or fixed to prevent aerosolization of contaminants.

\section{Input Requirements Based on Waste Classification}

A system must be able to retrieve and process waste that is within the range of physical characteristics previously described and that may be contaminated with some or all of the radionuclides and hazardous constituents listed in Table $\mathrm{C}-2$ such that it is not high-level waste or spent fuel.

\section{Output Requirements}

\section{Output Requirements Based on Waste Classification and Waste Acceptance Criteria}

Output wastes of a configuration option must fall into one of the following seven categories: "clean" waste, low-level waste, hazardous waste, TRU, TRU-mixed wastes, low-level mixed waste, or atypical wastes. All packaged final "clean," low-level, TRU, hazardous, low-level mixed, and TRU-mixed waste forms must meet applicable waste acceptanee criteria and Applicable or Relevant and appropriate requirements (ARARs). Waste Acceptance Criteria (WAC) requirements are outlined below.

"Clean" Waste

Without a legal, enforceable definition of "Below Regulatory Concern," all waste exhibiting characteristics of being radioactive will be considered radioactive waste. Radioactive wastes, for the purposes of this analysis, are defined as wastes containing naturally occurring radionuclides that are in concentrations greater than naturally occurring and/or any measurable amount of man-made radionuclides. Background levels of naturally occurring radionuclides have been determined in soil samples in towns surrounding the INEL. ${ }^{5}$ Naturally occurring radionuclides buried in OU 7-13 that must be remediated down to background levels include Thorium-232, Uranium-238, Uranium-234, and Radium-226. The background levels for these radionuclides are: 
Tabie C-2. Waste Constituents Disposed of in TRU Waste Pits and Trenches at the SDA (see References 3 and 4 ).

Radionuclides" ${ }^{a}$ (half-life)

Aluminum-26 $\left(8 \times 10^{5} \mathrm{y}\right)$

Amcricium-241 (458 y)

Californium-252 (sf $85 \mathrm{y}$ )

Carbon-14 (57.30 y)

Cesium-137 (30 y)

Chlorine-36 $\left(3 \times 10^{5} y\right)$

Cobalt $-60(5.23 \mathrm{y})$

Curium-244 (17.6 y)

Neptunium-2.37 $\left(2.14 \times 10^{6} \mathrm{y}\right)$

Nickcl-63 (92 y)

Plutonium-238 (86.4 y)

Plutonium-2.39 $(24,390$ y)

Plutonium-240 $(6580 \mathrm{y})$

Plutonium-241 (13.2 y)

Plutonium-242 $\left(3.8 \times 10^{5} \mathrm{y}\right)$

Radium-226 (1602 y)

Strontium-90 (28.1 y)

Thallium-204 (3.81 y)

Thorium-232 $\left(1.41 \times \mathrm{i} 0^{10} \mathrm{y}\right)$

Tritium (12.3 y)

Uranium-23.3 $\left(1.6 \times 10^{5} y\right)$

Uranium-234 $\left(2.47 \times 10^{5} \mathrm{y}\right)$

Uranium-235 $\left(7.1 \times 10^{8} \mathrm{y}\right)$

Uranium-238 (4.51 x $\left.10^{9} \mathrm{y}\right)$

Yttrium-91 (58.8d)

Inorganics

Alumina Brick

Argon (gas)

Asbestos

Beryllium Oxide

Calcium Silicate

Chrome Brick

Euxenite Ore Residue

Graphite

Hydrated Aluminum Oxides

Hydrated Iron Oxides

Hydrated Magnesium Oxides

Hydrated Plutonium Oxides

Hydrated Silicon Oxides

Hydrochloric Acid
Metals

Aluminum

Beryllium

Copper

Iron

Lead

Lithium

Magnesium

Mercury

Molybdenum

Platinum

Potassium ( $\mathrm{NaK}$ )

Sodium Mctal

Stainless Steel

Tantalum

Tin

Yttrium as $\mathrm{Y}_{2} \mathrm{O}_{3}$

Zircaloy

Zirconium

Zinc

\section{Organics}

Acetic Acid

Acetic Anhydride

Anthracene

Benzene

Santo Wax

Butyl Stearate

Carbon Tetrachloride

Cellulose

Diisopropyl Fluorophosphate

Dimethyl $(1,4$ bis-

phenyloxazolyl benzene)

Diphenyls

Ether

Ethylene Glycol 
Table C-2. (continued)

Inorganics (continued)

Hydrofluoric Acid

Iron Oxides

Lime

Lithium Hydride

Nitric Acid

Perchloric Acid

Portland Cement

Silica

Sulfuric Acid

Thallium Oxide

Uranium-Zirconium Hydride

Zirconia Brick

$\underline{\text { Saits }}$

Barium Carbonate

Barium Fluoride

Iron Chlorides

Potassium Nitrate

Sodium Chloride

Sodium Nitrate

Thorium Iluoride

Uranium Fluoride

Radium Salts

Metal Chlorides

Miscellancous Oils

Gcarbox Oil

Hydraulic Oil

Machining Oil

Spindlc Oil
Organics (continued)

Formalin and Formaldehyde

Freon

Gasoline

Methocel 400

Methyl Alcohol

3-methylcholanthrene

Nitrobenzene

Nitrocellulose

Organophosphates

Paraffin

Perchloroethylene

Polyethylene

Polychlorinated Biphenyls

Polyvinyl Chloride

Polyurethane Foam

Sodium Isobutyrate

Texaco Regal Oil

Terphenyls (ortho, meta, and para)

Toluene

1,1,1-Trichloroethane

Trichloroethylene

Varsol

VERSENE (Ethylene Diamineetetraacetic

Acid)

Xylene

\section{Unidentified Items}

Acids

Alchohols

Amino Acids

Esters

Insecticides

Plastics

Proteins

Pyrimidines

Solvents

a. References 3 and 4 list mixed fission products, mixed activation products, and unidentified beta/gamma emitters as being present in the wastes. For the purposes of this study, those categories of radionuclides will include only a mixture of radionuclides found in Table C-2. 
Thorium-232-13 $\pm 3 \mathrm{pCi} / \mathrm{g}$

Uranium-238-14 $\pm 3 \mathrm{pCi} / \mathrm{g}$

Uranium-234- $14 \pm 3 \mathrm{pCi} / \mathrm{g}$

Radium-226 - $14 \pm 3 \mathrm{pCi} / \mathrm{g}$.

Determining whether a waste is contaminated with man-made radionuclides is dependent upon the lower threshold at which state-o[-the-art radiation detection systems can measure radiation. Therefore, for the purposes of this analysis, all wastes contaminated with the remainder of radionuclides in Table C-2 at any point in time will always be considered radioactive.

\section{Low-Level Wastes}

For the purpose of this analysis, low-level waste (soil/debris) is defined as waste that contains radioactivity and is not classified as high-level waste, transuranic waste, spent fucl, or by-product material as defined in Section 11e(2) of the Atomic Energy Act. ${ }^{6}$ Test specimens of fissionable material irradiated for research and development only, and not for the production of power or plutonium, may be classified as low-level waste, provided the concentration of transuranic is less than $10 \mathrm{nCi} / \mathrm{g}$. A limit of $10 \mathrm{nCi} / \mathrm{g}$ was chosen over the regulatory limit of $100 \mathrm{nCi} / \mathrm{g}$ for transuranics because all low-level waste generated in systems will be eventually disposed of at the INEL Radioactive Waste Management Complex (RWMC) that considers waste with $<10 \mathrm{nCi} / \mathrm{g}$ transuranics low-level waste.

Therefore, all low-level wastes shipped to the RWMC for disposal must meet RWMC waste acceptance criteria outlined in DOE/L.D-10112 Rev. 4 entitled, "INEL Low-Level Radioactive Waste Acceptance Criteria."

Hazardous Wastes

For the purpose of this analysis, hazardous waste is defined as those waste types containing constituents in Table C-2 that are considered to be hazardous by EPA regulation Title 40 Code of Federal Regulations Part 261 (40CFR261). All hazardous wastes originating from a configuration option will be packaged and shipped to the INEL Hazardous Waste Storage Facility (HWSF) for interim storage. Therefore, all hazardous wastes must meet HWSF waste acceptance criteria. ${ }^{8}$

Pure TRU and TRU-Mixed Wastes

For the purpose of this analysis, TRU waste is defined as waste that is contaminated with alpha-emitting transuranium radionuclides with half-lives greater than 20 years and concentrations greater than $10 \mathrm{nCi} / \mathrm{g}$ at the time of assay. Transuranic-mixed wastes will be defined in this study as those waste types containing both (a) constituents in Table C-2 considered to be hazardous by 40 CFR261 and (b) radioactive constituents listed in Table C-2.

Currently, there is no repository for the disposition of exhumed TRU and TRU-mixed wastes. A limit of $10 \mathrm{nCi} / \mathrm{g}$ was chosen over the regulatory limit of $100 \mathrm{nCi} / \mathrm{g}$ for tranuranics because all pure TRU and TRU-mixed wastes originating from a configuration option are assumed to be packaged and sinipped to the INEL for interim storage. The INEL RWMC will not accept waste with a concentration of transuranics $>10 \mathrm{nCi} / \mathrm{g}$ for low-level waste disposal. TRU and TRU-mixed wastes 
shipped to the RWMC for interim storage must meet all requirements outlined in DOE/ID-10074, a revised draft of a report entilled, "INEL Transuranic Waste Acceptance Criteria.""

\section{Low-Level Mixed Waste}

Low-level mixed wastes will be defined in this study as those waste types containing constituents in Table C-2 considered to be hazardous by 40CFR261 and containing radioactive constituents listed in Table C-2. Currently, there is no repository for the disposition of exhumed lowlevel mixed wastes. Therefore, all low-level mixed wastes originating from a system option are assumed to be packaged and shipped per the INEL Radioactive Mixed Waste Storage Facility (MWSF) waste acceptance criteria ${ }^{10}$ for interim storage.

\section{Atypical Wastes}

Wastes outside the bounds of the requirements listed in Input Requirements Based on Physical Characteristics of Waste section of this Appendix for the purposes of this study, will be considered atypical waste and the system shall characterize them and leave them in the excavated pit or trench. Retrieval, processing, treatment, or packaging of atypical wastes discovered during a configuration option will not be considered in this phase of the analysis.

\section{ARARs}

The statutory and regulatory basis for compliance with ARARs during the remediation of INEL OU 7-13 is contained in CERCLA Section 121, Cleanup Standards; NCP Subpart E "Hazardous Substances Response"; and the INEL Federal Facility Agreement/Consent Order. CERCLA Section 121 (d) (2) requires that remedial actions comply with ARARs for any hazardous substance, pollutant or contaminant remaining onsite. Table C-3 is a preliminary list of Federal ARARs and DOE orders that will be used to define output requirements in the BIVID Systems Analysis. This information was adopted from preliminary ARARs identified for the INEL Pad A in a letter from S. G. Stiger to W. N. Sato (SGS-515-91). ${ }^{11}$ It should be noted that State and local ARARs are not considered in the BWID Systems Analysis. Federal ARARs are assumed at this point in time to adequately represent all cleanup restrictions. A final list of ARARs (Federal, State, and Local) will be refined by Environmental Restoration through the RI/FS process. 
Table C-3. Preliminary list of ARARs to be used in the BWID systems analysis.

Statute

Safe Drinking Watcr Act

$\underline{\text { Regulation }}$

40 CFR Part 141, National Primary Drinking Water Standards

40 CFR Part 141, Maximum Contaminant Level Goals

40 CFR Part 143, National Secondary Drinking Water Standards

\section{$\underline{\text { Stalute }}$}

Atomic Energy Act and Encrgy Reorganization Act

$\underline{\text { Regulation }}$

10 CFR Part 20, US Nuclear Regulatory Commission (NRC) Standards for Protection Against Radiation

10 CFR Part 60, Technical Requirements for Land Disposal Facilities

10 CFR Part 61, Licensing Requirements for Land Disposal of Radioactive Waste

\section{$\underline{\text { Statute }}$}

Resource Conservation and Recovery Act

$\underline{\text { Regulation }}$

40) CFR Part 241, Guidelines for Land Disposal of Solid Waste

40) CFP. Part 257, Criteria for Classification of Solid Waste Disposal Facilities and Practices

40) CFR Part 260, Hazardous Waste Management Systems

40) CFR Part 261, Identification and Listing of Hazardous Waste

40 C.FR Part 262, Standards Applicable to Generators of Hazardous Waste

40 CFR Part 263, Standards Applicable to Transporters of Hazardous Wastes

40 CFR Part 264, Maximum Concentration Limits 
Table C-3. (continued)

40) CFR Part 265, Requirements for Interim Status Facilities

40 CFR Part 268, Land Disposal Restrictions

$\underline{\text { Statule }}$

Clcan Air Act

Regulation

40 CFR Part 50, National Primary and Secondary Ambient Air Quality Standards

40 CFR Part 61, National Emission Standards for Hazardous Air Pollutants

4) CFR Part 61.90), National Standards for Radionuclide Emissions from DOE Facilities

Statule

Occupational Health and Safety Act

Regulation

40 CFR Part 1910, Occupational Health \& Salecy Standards

29 CFR part 1926, Health and Safety Standards for Construction

The following U.S. DOE Orders, although not typically considered ARARs, will also be considered as outpul requirements:

\section{DOE Orders}

5480.1B Environment, Safety and Health Program for DOE Operations

5480.3 Hazardous and Radioactive Mixed Waste Management

5480.4 Environmental Protection. Safety and Health Protection Standards

5820.2A Radioactive Waste Management

5400.5 Radiation Protection of the Public and the Environment 
Table C-3. (continued)

5480.11 Radiation Protection of Occupational Workers

6430.1A General Design Criteria

C -13 


\section{REFERENCES}

1. Federal Facility Agreement and Consent Order, ADN: 1088-06-29-120, Idaho National Enginecring Laboratory, May 1991.

2. U.S. Department of Encrgy, Environmental Restoration and Waste Management Five-Year Plan, Fiscal Years 1993-1997, August 1991.

3. D. A. Arrenholz and J. L. Knight, A Brief Analysis and Description of Transuranic Wastes in the Subsurface Disposal Area of the Radioactive Waste Management Complex at INEL, EGG-WTD-9438 Rev. 1, 1991.

4. D. A. Arrenholz and J. L. Knight, Historical Report of Transuranic Waste Pits And Trenches "It The Subsurface Disposal Area of The Radioactive Waste Management Complex at The INEL, WTD-91-027, August 1991.

5. $\quad$ K. L. Martin et al., Preliminary Assessment of Surface Soils at Active EG\&G Idaho Facilities Data Document, EGG-ESQ-9225, September 1990.

6. U.S. Department of Energy Radioactive Waste Management, DOE Order 5820.2A, September 26, 1988.

7. U.S. Department of Energy Idaho Field Office (DOE-ID), INEL Low-Level Radioactive Waste Acceptance Criteria, DOE/ID-10112 Rev. 4, October 1991.

8. U.S. Department of Energy Idaho Field Office (DOE-ID), Hazardous Waste Storage Facility Waste Acceptance Criteria, DOE/ID-10179, January 1992.

9. U.S. Department of Energy, Idaho Field Office (DOE-ID), INEL Transuranic Waste Acceptance Criteria, DOE/ID-100074, May 1991.

10. U.S. Department of Energy, Idaho Field Office, Radioactive Mixed Waste Storage Facility Waste Acceptance Criteria, December 1986.

11. Transmittal of the Revised Pad A Technical Memorandum on the Preliminary Identification of Combined Federal and State Applicable or Relevant and Appropriate Requirements (ARARs), Letter from S. G. Stiger (INEL Environmental Restoration) to W. N. Sato (DOE-ID), SGS515-91, December 5, 1991. 
Appendix D

Filter Formula Derivation from CERCLA

D-1 


\section{Appendix D}

\section{Filter Formula Derivation from CERCLA}

The following is a list of equations used within the trade-off study function of the PBTSF to obtain system performance measure values, and eventually, figures-of-merit for effectiveness, implementability, and cost. A description of performance data used in each formula is also included. The formulas were derived from text found in EPA/G-85/003 (Guidance On Feasibility Studies Under CERCLA) and EPA/G-89/004 (Guidance for Conducting Remedial Investigations and Feasibility Studies under CERCLA). All page number references in the discussion were taken from EPA $540 / \mathrm{G}-85 / 0(1) 3$.

A description of how performance data error and performance measure error are propagated is also provided. Two assumptions were made to simplify the error propagation methodology:

- Performance data are assumed to be statistically independent.

- Uncertainties (error) associated with the performance data are assumed to be quoted as standard error that is defined as sigma (standard deviation) over the square root of $\mathrm{n}$ (number of observations). For example, if a vendor indicates that it requires 100 person-hours $+/-10$ person-hours to operate a backhoe during a particular remediation task, the performance datum would be 100 person-hours and the standard error would he 10 person-hours.

\section{A. Effectiveness}

1. Volume Reduction

Page 3-2, Sec. 3.1.1, paragraph 1: "Remedial alternatives should be evaluated in terms of their ability to perform intended lunctions, such as containment, diversion, removal, destruction, or treatment."

This score assesses the ability of the system to reduce waste volume. A measurable way of expressing this is net output volume divided by net input volume.

Performance Measure:

$E_{1}=1-V_{o} / V_{i}$

Performance Data:

$V_{0}=$ The volume $\left(\mathrm{m}^{3}\right)$ of output material from the process that requires monitoring and storage (includes any contaminated process material). 
$v_{i}=$ The volume $\left(\mathrm{m}^{3}\right)$ of waste matrix, overburden, and horizontal plume as defined in the input system requirements.

Performance Data Error Propagation:

Calculate the standard crror for the system performance data $V_{0}$ using:

$S E_{V_{0}}=\sqrt{\sum_{i=1}^{n} S E_{V_{o_{i}}}{ }^{2}}$

where

$\mathrm{SE}_{\mathrm{V}_{0}}=$ The Standard Error of the system performance data $\mathrm{V}_{0}$. $\begin{array}{ll}\mathrm{SE}_{\mathrm{V}_{o_{i}}}= & \text { The Standard Error of } \mathrm{V}_{0} \text { for the } \mathrm{i}^{\text {th }} \text { subelement in the technology process } \\ \text { option. }\end{array}$

$\mathrm{n}=$ The number of subelements in $\mathrm{tec}$ technology process option.

$V_{i}$ has been estimated from historical data; the concept of standard crror does not apply.

Performance Measure Error Propagation:

Calculate the standard error for the volume reduction performance measure $E_{1}$ using:

$S E_{E_{1}}-\frac{S E_{V_{0}}}{V_{i}}$

where

$\mathrm{SE}_{1:}=$ The Standard Error of the performance measure $\mathrm{E}_{1}$ (volume reduction).

$\mathrm{SE}_{\mathrm{V}_{0}}=$ The Standard Error of the system performance data $\mathrm{V}_{0}$.

$V_{i}=$ The volume $\left(\mathrm{m}^{3}\right)$ of waste matrix, overburden, and horizontal plume as defined in the input system requirements.

2. Waste Generation

Page 3-2, Sec. 3.1.1, paragraph 1: "Remedial alternatives should be evaluated in terms of their ability to perform intended functions, such as containment, diversion, removal, destruction, or treatment." 
This score assesses the ability of the system to minimize waste generation. A measurable way of expressing this is the ratio of the volume of contaminated process material to the volume of input wastc.

Performance Measure:

$E_{2}=1-\frac{V_{8}}{V_{1}}$

Performance Data:

$\mathrm{V}_{\mathrm{g}}=$ The volume $\left(\mathrm{m}^{3}\right)$ of contaminated process material produced by the system.

$V_{i}=$ The volume $\left(\mathrm{m}^{3}\right)$ of waste matrix, overburden, and horizontal plume as defined in the input system requirements.

Performance Data Error Propagation:

Calculate the standard error for the system performance data $\mathrm{V}_{\mathrm{g}}$ using:

$S E_{V_{i}}=\sqrt{\sum_{i=1}^{n} S E_{V_{8 i}}{ }^{2}}$

where

$\mathrm{SE}_{\mathrm{V}_{\mathrm{g}}}=$ The Standard Error of the system performance data $\mathrm{V}_{\mathrm{g}}$. $\mathrm{SE}_{\mathrm{V}_{\mathrm{gi}}}=\begin{aligned} & \text { The Standard Error of } \mathrm{V}_{\mathrm{g}} \text { for the } \mathrm{i}^{\text {th }} \text { subelement of the technology process } \\ & \text { option. }\end{aligned}$

$\mathrm{n}=$ The number of subelements in the technology process option.

$V_{i}$ has been estimated from historical data; the concept of standard error does not apply.

Performance Measure Error Propagation

Calculate the standard error for the waste generation performance measure using:

$S E_{E_{2}}=\frac{S E_{V_{e}}}{V_{i}}$

where

$\mathrm{SE}_{\mathrm{I}_{2}}=$ The Standard Error of the performance measure $\mathrm{E}_{2}$ (waste generation).

$\mathrm{SE}_{\mathrm{V}_{\mathrm{g}}}=$ The Standard Error of the system performance data $\mathrm{V}_{\mathrm{g}}$. 
$V_{i}=$ The volume $\left(\mathrm{m}^{3}\right)$ of waste matrix, overburden, and horizontal plume as defined in the input sustem requirements.

\section{Compliance with ARARs}

Page 3-2, Sec. 3.1.1, paragraph 2: "The user should establish which environmental and public health standards are relevant or applicable at the site and evaluate proposed alternatives according to those standards."

Compliance with ARARs is measured as the degree to which process-specific ARARs are satisficd.

Performance Measure:

$E_{3}=\frac{E}{E_{\max }}$

Performance Data:

$\mathrm{E}=$ The total number of process-specific ARARs satisfied by the technology process option.

$\mathrm{E}_{\max }=$ The total number of process-specific ARARs associated with any of the initial suite of technology process option being considered.

Performance Data Error Propagation:

The performance data for this measure are collected at the system level; the concept of a standard error does not apply.

Performance Mcasure Error Propagation:

The concept of a standard error does not apply in this case.

4. Flexibility of Design

Page 3-2, Sec. 3.1.1, paragraph 4: "Any special site or waste conditions that affect perlormance should be considered, and the design should be tailored to accommodate those conditions."

The llexibility of design performance measure assesses the flexibility of the system or subsystems after construction. The flexibility of the system is estimated by measuring the fraction of the system consisting of replaceable COTS (commercial off-the-shelf) parts or components. It assumes that systcms that have a high proportion of COTS parts can be modified more easily than systems that have a high proportion of custom parts. (Sec definitions for COTS) 
Performance Measure:

$E_{4}=\frac{F_{s}}{F_{t}}$

Performance Data:

$\mathrm{F}_{\mathrm{s}}=$ The number of functional subelements within a configuration option whose requirements are satisfied with commercial-off-the-shelf technologies (COTS).

$F_{1}=\quad$ The total number of functional sube'ments in the configuration option.

Performance Data Error Propagation:

The concept of a standard error does not apply in this context.

Performance Measure Error Propagation:

The concept of a standard error does not apply in this context.

5. Reconfigurability

Page 3-2, Sec. 3.1.1, paragraph 4: "Any special site or waste conditions that affect performance should be considered, and the design should be tailored to accommodate those conditions."

This score assesses the ability to reconfigure the system or subsystems after construction. A measurable way of estimating the reconfigurability of the system is to measure the total number of functional subelements. This assumes that systems that have many parts or operations can be modified more casily than systems that are composed of only a few parts or operations.

Performance Measure:

$E_{5}=\frac{F_{t}}{F_{\max }}$

Performance Data:

$\mathrm{F}_{\mathrm{t}}=$ The total number of functional subelements in the configuration option.

$\mathrm{F}_{\text {max }}=$ The maximum number of subelements in any of the initial suite of configuration options being considered.

Performance Data Error Propagation:

The concept of a standard error does not apply in this context. 
Performance Mcasure Error Propagation:

The concept of a standard error does not apply in this context.

\section{Robustness}

Page 3-2, Sec. 3.1.1, paragraph 4: "Any special site or waste conditions that affect performance should be considered, and the design should be tailored to accommodate those conditions."

This is a measure of the system's ability to accommodate unanticipated inputs without modification to the system.

Performance Measure:

$E_{6}=\frac{N_{O S}}{N_{\max }}$

Performance Data:

$\mathrm{N}_{O S}=$ The number of predefined out of scope inputs as defined in the input system requirements that the system can remediate.

$\mathrm{N}_{\max }=$ The number of predefined out of scope inputs defined in the input system requirements.

Performance Data Error Propagation:

The concept of a standard error does not apply in this context.

Performance Mcasure Error Propagation:

The concept of a standard crror does not apply in this context.

\section{Expected Liletime}

Page 3-3, Sec. 3.1.2, paragraph 1: "Each alternative should be evaluated in terms of the projected service lives of its component technologics."

This performance measure is intended to measure the ability of the system to remain operational throughout the remediation process. It is measured as the ratio of the expected time until the line item and capital equipment replacement costs necessary exceed $50 \%$ of the acquisition cost to the total remediation time. 
Performance Measure:

$E_{7}=\frac{T_{l}}{T_{r}}$

Performance Data:

$\mathrm{T}_{1}=$ The time until line item and capital equipment replacement costs exceed $50 \%$ of acquisition cost. $T_{1}$ is obtained by first integrating the sum of all line item and capital equipment replacement costs for each technology over time. $T_{1}$ is the point in time when this integral equals half the system acquisition cost.

$\mathrm{T}_{\mathrm{r}}=$ The time it will take to remediate $\mathrm{V}_{\mathrm{i}}$.

Performance Data Error Propagation:

The concept of a standard error for $T_{r}$ does not apply in this context.

Performance Measurc Error Propagation:

Calculate the expected lifetime performance measure standard error using:

$S E_{E_{\eta}}=\sqrt{\frac{S E_{T_{l}}^{2}}{T_{r}^{2}}+\frac{T_{l}^{2} \times S E_{T_{r}}^{2}}{T_{r}^{4}}}$

where

$\mathrm{SE}_{1 ;}=$ The Standard Error on the performance measure $\mathrm{E}_{7}$ (expected lifetime).

$\mathrm{SE}_{\mathrm{T}_{1}}=$ The Standard Error on the system performance data $\mathrm{T}_{1}$.

$\mathrm{SE}_{\mathrm{T}_{\mathrm{r}}}=$ The Standard Error on the system performance data $\mathrm{T}_{\mathrm{r}}$.

$T_{1}=$ The time until line item and capital equipment replacement costs exceed $50 \%$ of acquisition cost.

$\mathrm{T}_{\mathrm{r}}=$ The time it will take to remediate $\mathrm{V}_{\mathrm{i}}$.

This formula has been derived from the normal law of errors, ${ }^{\mathrm{C}}$ which states that

$\alpha^{2}=\left(\frac{8 F}{\delta m_{i}}\right)^{2} \alpha_{1}^{2}+\left(\frac{8 F}{\delta m_{i}}\right)^{2} \alpha_{2}^{2}+\ldots+\left(\frac{\delta F}{\delta m_{i}}\right) \alpha_{n}^{2}$

c. J. Topping, Errors of Observation and Their Treatment, Chapman and Hall Limited, London, 1966. 
where
$\alpha=$ The standard crror of the function
$\mathrm{F}=$ The function being considered
$\mathrm{m}_{\mathrm{i}}=$ The means which comprises $\mathrm{F}$
$\alpha_{i}=$ The standard crrors associated with $m_{i}$.

Note that by using the formula we have assumed $T_{1}$ and $T_{r}$ are means from Gaussian distributions.

8. Availability

Page 3-3, Sec. 3.2.1, paragraph 1: "Technologies requiring frequent or complex operation and maintenance activities should be regarded as less reliable than technologies requiring little or straightforward operation and maintenance." Availability is measured as the fraction of time ruring the remediation process that the system is available.

Performance Measure:

$E_{8}=A$

Performance Data:

$\mathrm{A}=$ The fraction of time during the remediation process that the system is available. The system performance data $A$ is the product of all subelement availabilities. The availability of a subelement is the fraction of time during the remediation process that the subelement is available.

Performance Data Error Propagation:

Calculate the performance data error propagation for $\mathrm{A}$ using:

$S E_{A}=\prod_{j=1}^{n} A_{j} \times \sqrt{\sum_{i=1}^{n}\left(\frac{S E_{A_{i}}}{A_{i}}\right)^{2}}$

where

$\mathrm{SE}_{\mathrm{A}}=$ The Standard Error of the system performance data A (availability).

$S E_{\Lambda_{i}}=$ The Standard Error of $i^{\text {th }}$ subelement's availability.

$A_{j}=$ The availability of $j^{\text {th }}$ subelement.

$A_{i}=$ The availability of the $i^{\text {th }}$ subelement. 
$\mathrm{n}=$ The number of subelements in the technology process option.

$\mathrm{j}=$ The number of subelements in the technology process option.

This formula assumes subelement availabilities are from independent, Gaussian distribution (see $\left.\mathrm{SE}_{1 ;}\right)$.

Perlormance Measure Error Propagation:

The performance measure $E_{8}$ is identical to the system performance data $A$. The standard error for $\mathrm{E}_{8}$ is $\mathrm{SE}_{\mathrm{A}}$ in the formula above.

9. Throughput

Page 3-2, Sec. 3.1.1, paragraph 1: "Remedial alternatives should be evaluated in terms of their ability to perform intended functions."

Throughput is measured as the time per unit of waste remediated.

Performance Measure:

$E_{9}=\frac{K_{s} T_{r}}{V_{i}}$

Performance Data Roll-Up:

$\mathrm{T}_{\mathrm{r}}=$ The time (years) to remediate $\mathrm{V}_{\mathrm{i}}$.

$V_{\mathrm{i}}=$ The volume $\left(\mathrm{m}^{3}\right)$ of waste matrix, overburden, and horizontal plume as defined in the input system requirements.

$\mathrm{K}_{\mathrm{s}}=$ A site specific normalizing constant $\left(\mathrm{m}^{3} / \mathrm{year}\right)$ that will force the performance measure to be between 0 and 1 .

Performance Data Error Propagation:

The performance data $T_{r}$ is collected at the system level. No performance data error propagation occurs. $V_{i}$ has been estimated from historical data; the concept of standard crror doesnot apply.

Pcrformance Measure Error Propagation:

Calculate the standard error for the performance measure $\mathrm{E}_{9}$ using:

$S E_{E_{g}}=\frac{V_{i} \times S E_{r_{r}}}{1000 \times T_{r}^{2}}$

where 


$$
\begin{aligned}
& \mathrm{SE}_{1:}=\text { The Standard Error of the performance measure } \mathrm{E}_{9} \text { (throughput) } \\
& \mathrm{SE}_{\mathrm{r}}=\text { The Standard Error of the system performance data } T_{r} \\
& \mathrm{~V}_{\mathrm{i}}=\text { The volume }\left(\mathrm{m}^{3}\right) \text { of waste matrix, overburden, and horizontal plume as defined } \\
& \text { in the input system requirements. } \\
& \mathrm{T}_{r}=\text { The time (years) to remediate } V_{i} .
\end{aligned}
$$

10. Fffective Benefit

Page 3-5, Sec. 3.3.2.2, paragraph 1: "The user should evaluate each alternative in terms of the lime it lakes :o see beneficial results in the environment, exclusive of measures that provide temporary protection."

Effective benefit is measured as the time required to remediate $50 \%$ of the waste.

Performance Measure:

$E_{10}-1-\frac{T_{h}}{T_{\max }}$

Perlormanic Data:

$\mathrm{T}_{\mathrm{h}}=$ The time (years) to remediate $50 \%$ of $\mathrm{V}_{\mathrm{i}}$.

$T_{\text {max }}=$ The maximum time (years) allowed for the remediation process.

Performance Data Error Propagation:

The performance data for this measure are collected at the system level. The concept of standard crror does not apply.

Performance Measure Error Propagation:

The standard error for the performance measure $\mathrm{E}_{10}$ (effective benefii) is calculated using: $S E_{E_{10}}-\frac{S E_{T m}}{T_{\max }}$

where:

$$
\begin{aligned}
& S E_{1:}=\text { The Standard Error of the performance measure } E_{10} \text { (cllective benefit). } \\
& S E_{1 h}=\text { The Standard Error of the system performance data } T_{h} . \\
& T_{\text {max }}=\text { The maximurn time (years) allowed for the remediation process. }
\end{aligned}
$$




\section{Environmental/Public Health}

Page 3-5, Sec. 3.4, paragraph 1: "Each remedial alternative should be evaluated with regard to salety. This evaluation should include short-term and long-term threats to the safely of nearby communities and environments as well as those to workers during implementation. Major risks to consider are fire, explosion, and exposure to hazardous substances resulting due to both on-sile and off-site activities during remedial action implemention."

This seore assesses the ability of the system to maintain a safe environment. A measurable way of expressing this is the ratio of the capital costs defined as "important-to-safety" to the life-cycle cost of the system. Labor costs are not incorporated in this measure.

Perlormance Mcasure:

$E_{11}=1-\frac{C_{i s}}{C_{m}}$

Performance Data:

$\mathrm{C}_{\mathrm{is}}=$ The total capital expenses that are "important-to-salety" items.

$C_{m}=$ The total life-cycle cost.

Performance Data Error Propagation:

The performance data for this measure are collected at the system level. The eoncept of standard error does not apply.

Performance Measure Error Propagation:

The concept of standard errot is not applicable in this context.

\section{B. Implementability}

\section{Technical Risk}

Page 3-3, Sec 3.2.2, paragraph 1: "The user should give prelerence to technologies that have proven eflective under waste and site conditions similar to those anticipated.

Technical Risk is assessed as the proportion of the system that has been demonstrated under similar waste and site conditions, plus the proportion of the system that is similar to technology demonstrated under similar waste and site conditions. 
Perlormance Measure:

$l_{1}=\frac{C_{d}+C_{s}}{F_{t}}$

Performance Data:

$\mathrm{C}_{\mathrm{d}}=$ The number of subelements in a configuration option whose requirements are satisfied with technologies that have been demonstrated under similar site and waste conditions.

$\mathrm{C}_{\mathrm{s}}=$ The number of subelements in a configuration option whose requirements are satisfied with technologies that are similar to technologies demonstrated under similar site and waste conditions.

$F_{1}=$ The total number of subelements in a configuration option.

Performance Data Error Propagation:

The pertormance data for this measure are collected at the system level. The concept of standard error does not apply.

Performance Measure Error Prepagation:

The concept of standard error is not applicable in this context.

2. Non-Carcinogenic Safery Risk

Page 3-5, Sec. 3.4, paragraph 1: "Each remedial alternative should be evaluated with regard to salety. This evaluation should include short-term and long-term threats to the safety of nearby communitics and environments."

This score assesses the ability of the system to maintain a safe environment. A measurable way of expressing this is the ratio of the Hazard Index with the process to the Hazard Index without the process.

Perlormance Measure:

$I_{2}-1 \frac{R_{p}}{R_{r p}}$

Pertormance Data:

$R_{p}=$ The Hazard Index with the process.

$R_{\mathrm{np}}=$ The Hazard Index without the process. 
Performance Data Error Propagation:

The performance data for this measure are collected at the system level. The concept of standard crror does not apply.

Performance Measure Error Propagation:

The concept of standard error is not applicable in this context.

\section{Carcinogenic Safety Risk}

Page 3-5, Sec. 3.4, paragraph 1: "Each remedial alternative should be evaluated with regard (o) salcly. This evaluation should include short-term and long-term threats to the safety of nearby communitics and environments."

This score assesses the ability of the system to maintain a safe environment. A measurable way of expressing this is the ratio of the Caneer Incidence with the process to the Cancer Incidence without the process.

Performance Mcasure:

$I_{3}=1 \frac{R_{p c}}{R_{n p c}}$

Performance Data:

$\mathrm{R}_{\mathrm{pc}}=$ The Cancer Incidence with the process.

$R_{\text {wp }}=$ The Cancer Incidence without the process.

Performance Data Error Propagation:

The performance data for this measure are collected at the system level. The concept of standard crror does not apply.

Performance Measure Error Propagation:

The concept of standard error is not applicable in this context.

\section{System Implementability}

Page 3-4, Sec 3.3.1.1, paragraph 1: "The ability to actually build, construct, or implement the remedial technology on the site must be assessed.

The demonstrability of the system is assessed using the fraction of subelements not able to be demonstrated before full-scalc implementation. 
Performance Measure:

$I_{4}=1-\frac{C_{n}}{F_{i}}$

Performance Data:

$\mathrm{C}_{\mathrm{n}}=$ The number of subelements in the configuration option whose requirements are satislied with technologies that are not able to be demonstrated prior to full-scale implementation.

$F_{1}=$ The total number subelements in the configuration option. Note: $F_{1}=C_{n}+C_{d}$ $+\mathrm{C}_{\mathrm{s}}+$ demonstratable, but not demonstrated subelements.

Performance Data Error Propagation:

The performance data for this measure are collected at the system level. The concept of standard crror is not applicable.

Performance Measure Error Propagation:

The concept of standard error is not applicable in this context.

\section{Site Conditions}

Page 3-4, Sec 3.3.1.1, paragraph 1: "The ability to actually build, construct, or implement the remedial technology on the site must be assessed.

The performance measure for site conditions is based on the ratio of the number subelements previously fielded and operated in a similar environment 10 the number of subelements in the system.

Performance Measure:

$I_{s}=\frac{C_{d}+C_{s}}{F_{t}}$

Performance Data:

$\mathrm{C}_{\mathrm{d}}=$ The number of subelements in a configuration option whose requirements are satisfied with technologies that have been demonstrated under similar site and waste conditions.

$\mathrm{C}_{\mathrm{s}}=$ The number of subelements in a configuration option whose requirements are satisfied with technologies that are similar to technologies demonstrated under similar site and waste conditions.

$F_{1}=$ The total number of subelements in a conliguration option. 
Performance Data Error Propagation:

The performance data for this measure are collected at the system level. The concept of stanclard error does not apply.

Performance Méasure Error Propagation:

The performance data used to calculate the site conditions performance measure are assumed exact, so the standard error on the performance measure is assigned a value of 0 .

6. Conditions External to the Site - Permits

Page 3-4, Sec. 3.3.1.2 paragraph 2: "Certain remedial activities may require zoning clearances and local permits in addition to compliance with applicable State and Federal regulations."

The number of permits required to perform remediation activities is an indicator of regulatory complexity.

Performance Measure:

$I_{6}=\frac{1}{N_{p}+1}$

Performance Data:

$\mathrm{N}_{p}=$ Estimated gross number of permits required to perform the remediation.

Perlormance Data Error Propagation:

The concept of standard error does not apply in this context.

Performance Measure Error Propagation:

The concept of standard error does not apply in its context.

\section{Olf-Sitc Disposal}

Page 3-4, Sec 3.3.1.2, paragraph 1: "Conditions external to the site that affect the implementability of remedial technologies include the availability and acceptability of off-site disposal sites and the equipment availabic for construction."

Oll-Site (INEL) disposal is measured as the fracion of waste that cannot be moved to off-Site disposal. 
Performance Measure:

$I_{7}=1 \cdots \frac{W_{n o}}{V_{1}}$

Performance Data:

$\mathrm{W}_{\mathrm{no}}=$ The volume of waste that cannot be moved to off site disposal.

$\mathrm{V}_{\mathrm{i}}=$ The volume $\left(\mathrm{m}^{3}\right)$ of waste matrix, overburden, and horizontal plume as defined in the input system requirements.

Performance Data Error Propagation:

The performance data for this measure are collecied at the system level. The concept of standard error does not apply.

Performance Measure Error Propagation:

The standard error for the performance measure $\mathrm{I}_{7}$ is calculated using:

$S E_{l_{\gamma}}-\frac{S E_{W_{w}}}{V_{i}}$

where

$\mathrm{SE}_{1_{7}}=$ The Standard Error of the performance measure $\mathrm{I}_{7}$ (off-site disposal).

$\mathrm{SE}_{\mathrm{W}_{\mathrm{no}}}=$ The Standard Error of the system perlormance data $\mathrm{W}_{\mathrm{no}}$.

$V_{i}=$ The volume $\left(\mathrm{m}^{3}\right)$ of waste matrix, overburden, and horizontal plume as defined in the input system requirements.

8. Complexity of Operations - Automation

Page 3-3, Sec 3.2.1, paragraph 1: "... Also, the frequency and complexity of necessary operation and maintenance should be considered in evaluating the reliability of alternatives."

This performance measure estimates the level of automation as the ratio of operation hours per hour of labor.

Performance Measure:

$I_{8}=\frac{O}{L}$

Performance Datta:

$\mathrm{L}=$ The total labor hours required to operate the remediation system. 
$\mathrm{O}=$ The hours of operation required for the remediation.

Performance Data Error Propagation:

Calculate the standard error for the performance data $L$ using:

$S E_{L}=\sqrt{\sum_{i=1}^{n} S E_{L_{i}}{ }^{2}}$

where

$\mathrm{SE}_{\mathrm{l}}=$ The Standard Error on the system performance data $\mathrm{I}$.

$\mathrm{SE}_{\mathrm{L}_{i}}=$ The Standard Error of $\mathrm{L}$ for the $\mathrm{i}^{\text {th }}$ subelement in the technology process option.

$n=$ The number of subelements in the technology process option.

The performance data $\mathrm{O}$ is collected at the system level. The concept of standard error does not apply.

Perlormance Measure Error Propagation

Calculate the standard error for the perlormance measure $I_{8}$ using:

$S E_{l_{8}}=\sqrt{\frac{S E_{O}^{2}}{L^{2}}+\frac{O^{2} \times S E_{l}^{2}}{L^{4}}}$

where

$\mathrm{SE}_{\mathrm{P}_{8}}=\quad$ The Standard Error on the performance measure $\mathrm{I}_{8}$ (automation).

$\mathrm{SE}_{\mathrm{O}}=$ The Standard Error on the system performance data $\mathrm{O}$.

$\mathrm{SE}_{\mathrm{L}}=$ The Standard Error on the system performanec data $\mathrm{L}$.

$\mathrm{L}=$ The total labor hours required to operate the remediation system.

$\mathrm{O}=$ The hours of operation required for the remediation.

This formula assumes $\mathrm{O}$ and $\mathrm{L}$ are mean of independent Gaussian distribution (see $\mathrm{SE}_{1:}$ ).

9. Complexily of Operations - Training

Page 3-3, Sec 3.2.1, paragraph 1: "... Also, the frequency and complexity of necessary operation and maintenance should be considered in evaluating the reliability of alternatives." 
This performance measure is based on the mean years of specialized training required to operate the system.

Performance Measure:

$I_{9}=\frac{Y_{E D}}{Y_{\max }}$

Performance Data:

$\mathrm{Y}_{1: 1)}=$ The mean years of specialized training (academic and facility specific) required to operate the remediation system (the sum of each operator's educational requirements).

$\mathrm{Y}_{\text {Inax }}=$ The maximum mean years of specialized training required to operate any of the initial suite of remediation systems being considered.

Perlormance Data Error Propagation:

The concept of standard error does not apply in this context.

Performance Measure Error Propagation:

The concept of standard error does not apply in this context.

10. Time 10 Demonstrate

Page 3-5, section 3.3.2.1, paragraph 1: "Implementation time includes the time it takes for special studies, design, construction, and any other technical steps that may be required for implementation. The user should evaluate alternatives in terms of the most likely construction schedules, based on experience at similar sites or on a standard engineering procedure like critical path analysis."

Temporal risk is measured as the critical path time from initiation of design to initial operation at demonstration.

Performance Mcasure:

$I_{10}=1-\frac{T_{d}}{T_{\max }}$

Performance Data:

$\mathrm{T}_{\mathrm{d}}=$ The time required until the system can be demonstrated.

$\mathrm{T}_{\max }=\quad$ The maximum time (years) allowed for the remediation process. 
Performance Data Error Propagation:

The performance data for this measure are collected at the system level. The concept of standard crror is not applicable.

Performance Mcasure Error Propagation:

Calculate the performance measure error propagation for $I_{10}$ using:

$S E_{I_{10}}=\frac{S E_{t_{d}}}{T_{\max }}$

where

$\mathrm{SE}_{10}=$ The standard error of the performance measure $\mathrm{I}_{10}$ (time to demonstrate).

$\mathrm{SE}_{\mathrm{T}}=\quad$ The standard error of the system performance data $\mathrm{T}_{\mathrm{d}}$.

$\mathrm{T}_{\max }=\quad$ The maximum time (years) allowed for the remediation process.

11. Implementation Risk

Page 3-5, section 3.3.2.1, paragraph 1: "Implementation time includes the time it takes for special studies, design, construction, and any other technical steps that may be required for implementation. The user should evaluate alternatives in terms of the most likely construction schedules, based on experience at similar sites or on a standard engineering procedure like critical path analysis."

This performance measure is based upon the scheduled time from evaluation of design to beginning of operation.

$I_{11}=1-\frac{T_{b r}}{T_{\max }}$

Performance Data:

$\mathrm{T}_{\mathrm{br}}=$ The time it takes to build and begin operation of the remediaton system.

$\mathrm{T}_{\max }=$ The maximum time (years) allowed for the remediation process.

Performance Data Error Propagation:

The performance data for this measure are collected at the system level. The concept of standard error does not apply. 
Performance Mcasure Error Propagation:

Calculate the performance measure crror propagation for $I_{11}$ using:

$S E_{I_{11}}=\frac{S E_{T_{\mathrm{rr}}}}{T_{\max }}$

where

$\mathrm{SE}_{1_{11}}=\quad$ The standard error of the performance measure $\mathrm{I}_{11}$ (Implementation risk).

$\mathrm{SE}_{\mathrm{T}}=$ The standard error of the system performance data $\mathrm{T}_{\mathrm{br}}$.

\section{Cost}

1. Life Cycle Cost

Page 3-3, Sec 3.2.1, paragraph 1: "Evaluations of the operation and maintenance requirements of remedial alternatives should emphasize the availability of labor and materials as well as their costs. Also, the frequency and complexity of necessary operation and maintenance should be considered in evaluating the reliability of alternatives."

This is a measure of the total cost of the remediation system.

Performance Mcasure:

$C_{1}=1-\frac{C_{m}}{C_{m_{\text {max }}}}$

Performance Data:

$\mathrm{C}_{\mathrm{m}}$
$=$ The life cycle cost.
$\mathrm{C}_{\mathrm{m}}=$ The maximum lifecycle cost of all processes initially considered.

Perlormance Data Error Propagation:

Calculate the standard error for the system performance data $C_{m}$ using:

$S E_{c_{m}}=\sqrt{\sum_{i=1}^{n} S E_{C_{m i}}^{2}}$

where

$\mathrm{SE}_{\mathrm{C}_{\mathrm{m}}}=$ The Standard Error of the system performance data $\mathrm{C}_{\mathrm{m}}$.

$\mathrm{SE}_{\mathrm{C}_{\mathrm{mi}}}=\mathrm{The}_{\text {option. }}$ 
$\mathrm{n}=$ The number of subelements in the technology process option.

Performance Measure Error Propagation:

Calculate the standard error for the performance measure $C_{1}$ using:

$S E_{C_{1}}=\sqrt{\frac{S E_{C_{m}}}{\left(C_{m_{\text {max }}}\right)^{2}}+\frac{\left(C_{m} S E_{c m_{\text {Bax }}}\right)^{2}}{\left(C_{m_{\text {max }}}\right)^{4}}}$

where

$\mathrm{SE}_{\mathrm{C}_{1}}=$ The Standard Error of the performance measure $\mathrm{C}_{1}$ (life cycle cost).
$\mathrm{SE}_{\mathrm{C}_{\mathrm{m}}}=$ The Standard Error of the system performance data $\mathrm{C}_{\mathrm{m}}$.
$\mathrm{SE}_{\mathrm{C}_{\mathrm{m}}}=$ The standard error of the system performance data $\mathrm{C}_{\mathrm{m}}$.
$\mathrm{C}_{\mathrm{max}}$
$\mathrm{C}_{\mathrm{m}_{\max }}=$ The life cycle cost 

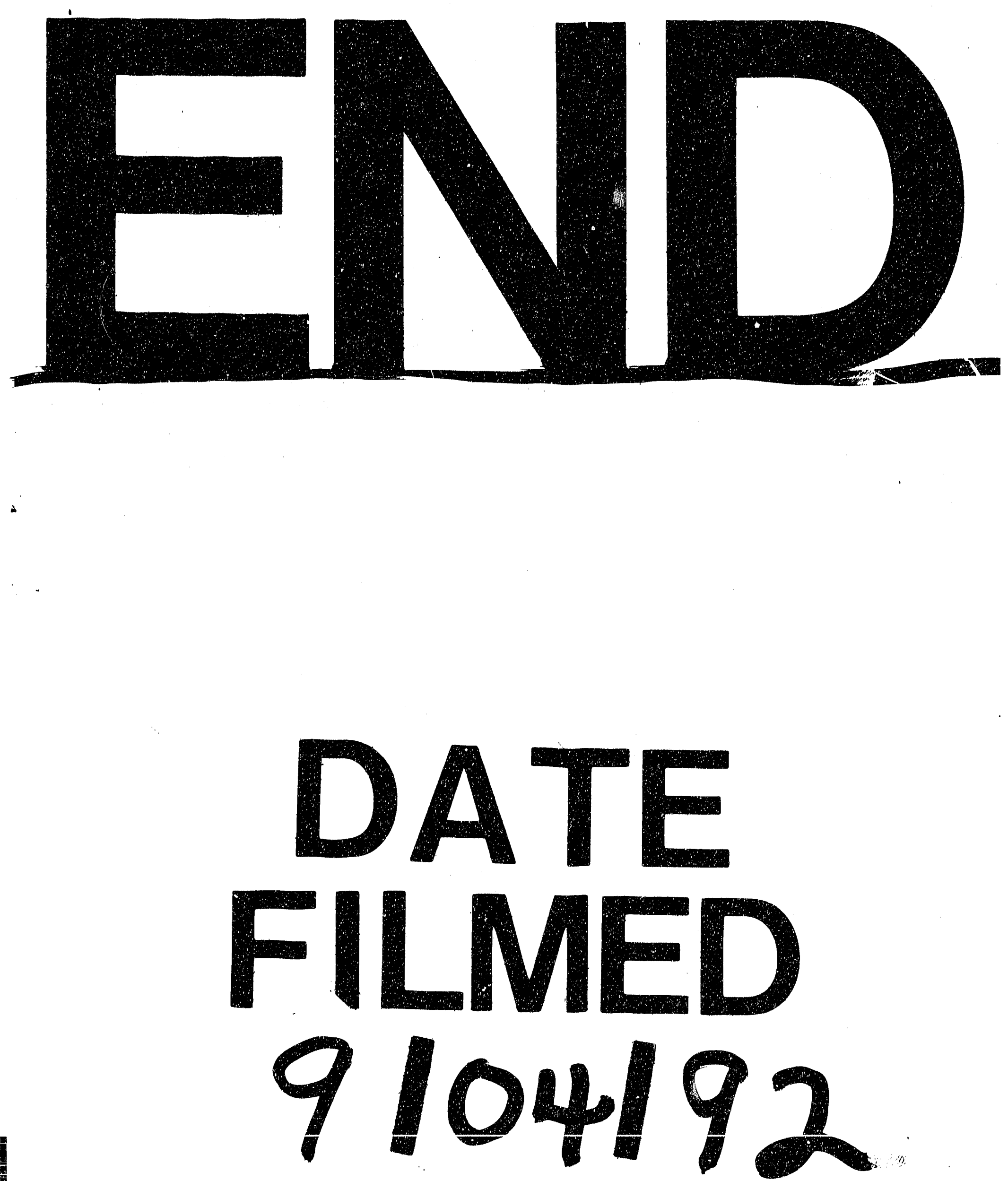
